\title{
Advances in bioprinted cell-laden hydrogels for skin tissue engineering
}

\author{
Rúben F. Pereira ${ }^{1,2,3,4}(\mathbb{C}) \cdot$ Aureliana Sousa $^{2,3}$ - Cristina C. Barrias ${ }^{2,3,4}$. \\ Ardeshir Bayat $^{5}$ - Pedro L. Granja ${ }^{2,3,4,6}$ • Paulo J. Bártolo ${ }^{7,8}$
}

Received: 14 July 2017/ Accepted: 17 July 2017/Published online: 8 August 2017

(C) Springer International Publishing AG 2017

\begin{abstract}
Bioprinting technologies are powerful additive biofabrication techniques to produce cellular constructs for skin tissue engineering owing to their unique ability to precisely pattern living and non-living materials in predefined spatial locations. This unique feature, combined with the computer controlled printing and medical imaging techniques, enable researchers and clinicians to generate patient specific constructs partly replicating the intricate compositional and architectural organization of the skin. Bioprinting has been used to automatically dispense hydrogels with skin cells located in prescribed sites that promote skin formation in vitro and in vivo. Current skin
\end{abstract}

Pedro L. Granja and Paulo J. Bártolo contributed equally to this work.

Rúben F. Pereira

ruben.pereira@ipleiria.pt

1 CDRsp-Centre for Rapid and Sustainable Product Development, Polytechnic Institute of Leiria, 2430-028 Marinha Grande, Portugal

2 i3S-Instituto de Investigação e Inovação em Saúde, Universidade do Porto, 4200-135 Porto, Portugal

3 INEB-Instituto de Engenharia Biomédica, Universidade do Porto, 4200-135 Porto, Portugal

4 ICBAS-Instituto de Ciências Biomédicas Abel Salazar, 4050-313 Porto, Portugal

5 Plastic and Reconstructive Surgery Research, Institute of Inflammation and Repair, University of Manchester, M1 7DN Manchester, UK

6 FEUP-Faculdade de Engenharia da, Universidade do Porto, 4200-465 Porto, Portugal

7 School of Mechanical, Aerospace and Civil Engineering, University of Manchester, M13 9PL Manchester, UK

8 Manchester Institute of Biotechnology, University of Manchester, M1 7DN Manchester, UK bioprinting approaches mostly rely on the sequential printing of fibroblasts and keratinocytes embedded within a homogeneous hydrogel. Although such approaches have already been translated to pre-clinical scenarios, they still present limitations in terms of fully replicating the cellular and extracellular matrix (ECM) heterogeneity in native skin. The success of bioprinting for skin repair strongly depends on the design of printable bioinks capable of supporting the function of printed cells and stimulating the production of new ECM components. To better mimic the human skin, novel developments in dedicated bioprinting technologies, in the design of bioinks, as well as in the printing of vascularised constructs are necessary. This paper presents an overview regarding the use of bioprinting for skin tissue engineering applications. The operating principles of bioprinting technologies are outlined along with requirements of printed skin constructs. Finally, preclinical results are summarized and future perspectives for the field are highlighted.

Keywords 3D bioprinting - Bioink - Extracellular matrix . Hydrogel $\cdot$ Skin $\cdot$ Tissue engineering

\section{Introduction}

The integumentary system comprises the skin and respective appendages (hair, nails and sweat glands) and is responsible for many vital functions in the body, such as the homeostasis, protection, and transmission of sensorial information [52, 149, 201]. Skin is the most superficial and the largest organ of the human body, acting as an efficient barrier at the interface between the internal organs and the external environment. However, the permanent exposure to environmental stresses may result in a variety of skin 
injuries induced by acute trauma, thermal, chemical, mechanical, microbial and radiation effects. Additional causes of skin loss also include genetic disorders, chronic wounds and surgical interventions [52, 176]. Depending on the lesion type, extension and depth, both superficial and deep skin layers may be damaged and the innate healing ability of skin may be dramatically reduced or inhibited. In the most critical clinical scenarios, such as deep dermal or third degree burns and full-thickness wounds, hypodermal adipose tissue, fascia, in addition to internal tissues and organs, may also be injured, leading to significant morbidity, dysfunctionality and potentially death [201]. Skin burns and chronic wounds represent one of the most debilitating, painful, and costly health conditions with a tremendous economic and social impact. Typically, these wounds require extensive hospitalization, labour intensive clinical procedures and costly wound care products, representing a major burden over total world healthcare expenditure [9, 153, 175].

Several skin therapies and wound care products have been developed and tested through pre-clinical and randomized controlled clinical trials with the ultimate goal of promoting the repair and regeneration of functional skin [44, 49, 84, 86, 88, 103, 124, 189, 195, 212]. Traditional treatments are based on the use of grafts (which includes auto-, allo- and xenograft varieties), herbal and animalderived compounds, silver-containing and traditional dressings. These therapies have been used since ancient times mainly due to their clinical efficacy, simplicity and affordability, offering a broad range of therapeutic effects, such as anti-inflammatory, cell stimulatory, antimicrobial, and wound debridement [98, 99, 145, 159, 179, 181]. However, in certain types of skin wounds, such as deep burns and chronic wounds, more sophisticated and effective treatments are usually needed [20, 50, 87, 212]. Advanced therapies assume a prominent role in the management of such wounds, as they explore the basic principles and elements of tissue engineering to produce both cellular and acellular constructs for skin regeneration [52, 109, 149]. In the most classical approach, known as scaffold-based or top-down, scaffolds are fabricated through either conventional or additive manufacturing processes, and subsequently seeded with autologous or allogeneic cells. The cellular scaffold is then cultured in vitro to produce a tissue-engineered construct for subsequent implantation into the lesion site $[66,116,146,177]$. Despite the fact that such an approach allows for a good control over the scaffold characteristics (when additive manufacturing processes are used) and cellscaffold interactions, it fails in placing individual cells at specific locations throughout the scaffold, thereby not mimicking the intricate cellular organization of natural tissues at micro- and nanoscale. Other important drawbacks are related with the limited cell density and insufficient vascularization, which may lead to tissue malformation and heterogeneous tissue growth [121, 148]. To address these limitations, an alternative approach, termed scaffold-free or bottom-up approach, has been used to generate 3D structures resembling the biological and functional organization of human tissues [71, 102, 129, 139, 172]. In this approach, one strategy of biofabrication, termed bioassembly, is applied to generate hierarchical constructs with a prescribed two-dimensional (2D) or 3D organization. Larger and complex tissue constructs are obtained through the automated assembly of pre-formed cell-containing fabrication units (e.g., cell aggregates, cell fibres, cell sheets or microtissues) produced by different techniques, such as self-assembled aggregation, microfabrication or microfluidics [10, 78, 129]. Bottom-up approach addresses some of the limitations of the top-down approach by the creation of tissue constructs with multiple cell types placed in specific 3D locations, with a high cell density and possibility of printing vascular networks [16, 121, 166]. Bioprinting, one main strategy of biofabrication, is attracting significant interest from researchers working in the field of tissue engineering and regenerative medicine due to their unique ability to print single cells, bioactive molecules, biomaterials or cell-aggregates into structurally organized constructs in a layer-by-layer fashion with high resolution and accuracy [10, 78, 111, 136]. Bioprinting provides a powerful tool to arrange cells, biomaterials and soluble factors within a $3 \mathrm{D}$ environment on a length scale comparable to the complex heterogeneity found in natural tissue (10-100 $\mu \mathrm{m})$, enabling new perspectives as well as unmatched possibilities in the design of biomimetic substitutes for tissue regeneration [10, 80, 125]. In the context of skin tissue engineering, bioprinting has been explored for the fabrication of $3 \mathrm{D}$ constructs containing skin cells positioned in distinct layers to resemble the anatomy of native skin [117, 184].

This review presents a detailed overview of the bioprinting processes as valuable technologies to produce cellladen constructs for skin tissue engineering, outlining the operating principles, processable biomaterials and preclinical results. Current challenges in the field will be also discussed mainly focusing on the design of advanced bioinks and the vascularization of skin constructs.

\section{Human skin properties and regeneration}

The human skin is a multilayer organ that presents limited self-regenerative properties after injury. In contrast to other vertebrates, such as amphibians and mammalian foetuses through mid-gestation, skin scarring is the inevitable and permanent endpoint in mammals [197]. To address the 
limited regenerative capability of adult skin and promote the restoration of skin barrier properties, there are diverse products and therapies available for clinical use (e.g., dressings, cell-based treatments and bioengineered skin substitutes) or currently under investigation (e.g., bioprinted cellular substitutes), showing promising outcomes.

\section{Skin structure and constituents}

The skin serves as a protective layer against the invasion of pathogens and external agents, playing a critical role in thermal regulation, homeostasis and transmission of sensorial information [142, 157, 201]. From an anatomical point, skin consists of three sequential layers of epidermis, dermis and hypodermis, each having distinct functions, biomechanical properties and cellular constituents (Fig. 1). Adnexal structures like nails, hair follicles, sweat, apocrine and sebaceous glands are responsible for cosmetic, protective and temperature regulation functions. Epidermis is the most superficial skin layer being composed of keratinized stratified squamous epithelium and organized in four or five main layers (Fig. 1) containing keratinocytes in different stages of proliferation, differentiation and keratinization $[157,178]$. Although the epidermis is an avascular layer, it is under constant renewal due to the presence of epidermal basal cells and stem cells in the basal layer and hair follicles [79]. The main cellular constituents include keratinocytes, melanocytes, Merkel cells and Langerhans cells $[13,149]$. The underlying dermis, separated from the epidermis by a basement membrane, is mainly composed of ECM molecules arranged in a dense matrix of connective tissue rich in collagen and elastin fibres that provides structural and mechanical support to the skin [15]. It is a highly dynamic, vascularized layer that supports the epidermis, provides flexibility and strength to the skin, and also contains blood vessels, sweat and sebaceous glands, hair follicles and sensory receptors [13, 115]. The predominant cells in dermis are heterogeneous subpopulations of fibroblasts, which are responsible for the production of connective tissue components [40]. Other cell types like mast cells and macrophages are also present, playing important roles in immune and inflammatory responses [13, 79]. The hypodermis, which acts as an energy source and heat insulator, is located just below the dermis and is mainly composed of adipose tissue and collagen, attaching the dermis to underlying tissues $[13,115]$.

\section{Wound healing process}

From the onset of injury, the human body initiates a series of complex and coordinated signalling pathways, involving the interaction between several ECM components, cells, cytokines and growth factors, aimed at tissue repair and

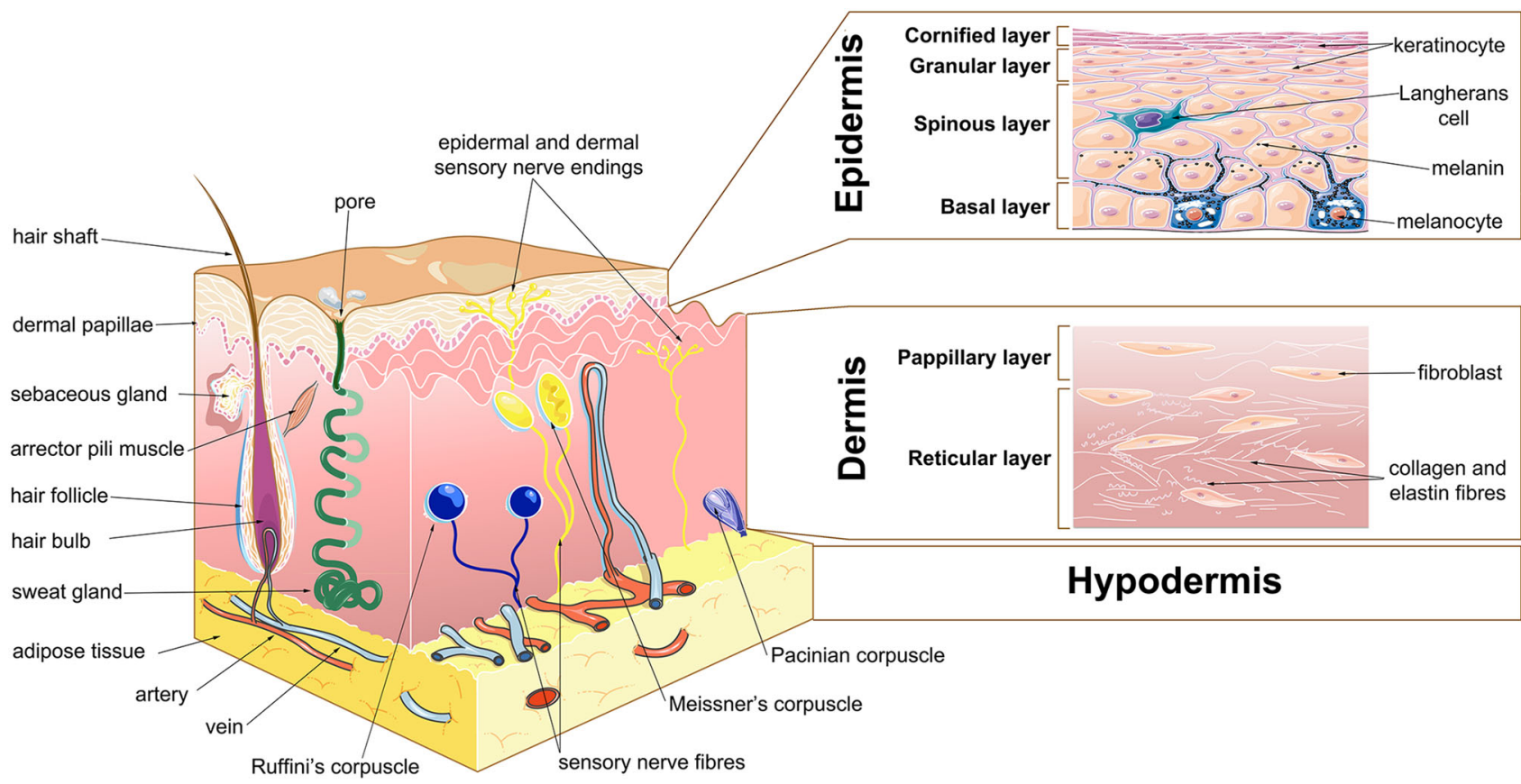

Fig. 1 Schematic representation of the multi-layered structure of human skin. Emphasis is given to the four main layers of epidermis and its cellular constituents, including keratinocytes, Langerhans cells and melanocytes. Two distinct regions of dermis are also represented along with fibroblasts and zonal organization of both collagen and elastin fibres. Specialized elements, such as sweat glands, hair roots, sensory cells, blood and lymph vessels are also presented. Skin structures are not to scale for simplification. Image from Servier Medical Art freeware image bank 
reconstruction of lost cutaneous tissue [110, 178]. The healing of an acute wound proceeds in a sequence of overlapping and well-orchestrated events throughout different phases of haemostasis, inflammation, migration, proliferation and maturation. The first response of the human body to an injury is haemostasis, which is mediated by platelets, and involves the formation of a fibrin clot that circumvents the bleeding, acts as a provisional ECM for cell migration, and loosely joins the wound edges [61, 188]. During haemostasis, platelets suffer degranulation and release a plethora of cytokines and growth factors (e.g. transforming growth factor- $\beta$ (TGF- $\beta$ ), fibroblast growth factor (FGF), transforming growth factor- $\alpha$ (TGF$\alpha$ ), vascular endothelial growth factor (VEGF), plateletderived growth factor (PDGF), and epidermal growth factor (EGF)) responsible for attracting inflammatory and vascular cells to the wound site $[61,110,113]$. In the inflammatory phase, neutrophils, monocytes (that differentiate into macrophages), lymphocytes and mesenchymal cells (that differentiate into fibroblasts) play a key role not only in the elimination of microbes and foreign particles, cellular debris and clearance of apoptotic cells, but also in the stimulation of keratinocytes, fibroblasts and endothelial cells $[61,110,113]$. Subsequently, the healing process continues with the formation of a scab and the migration and proliferation of epithelial cells. Keratinocytes, located at the wound periphery, are stimulated to migrate and proliferate into the lesion site to promote re-epithelialization by the synthesis of new epidermis [110]. Fibroblasts and endothelial cells are also recruited to initiate the synthesis of ECM components, the formation of a granulation tissue, and the growth of new blood vessels from existing ones $[51,61,178]$. Some of the fibroblasts located within the granulation tissue are converted into myofibroblasts, which are involved in wound contraction and re-epithelialization [51, 110, 113]. At the final stage, wound healing involves a long maturation phase, in which the wound edges move towards the centre (wound contraction), and the new tissue is continuously remodelled in order to approximate its properties to those of the native skin. This phase can take several weeks to months, and is marked by changes in the ECM composition with re-organization of collagen fibres and collagen crosslinking [110, 180]. Despite the continuous remodelling process, adult wound healing predictably results in a scar tissue with a tensile strength that only achieves $80 \%$ of its native properties, impairing the flexibility, mobility and esthetical outcomes [178].

\section{Therapeutic options for skin reconstruction}

The most suitable therapeutic treatment for skin wounds depends on numerous factors including the wound type, number of affected skin layers, level of exudate, extension of injury, and the overall health status of the patient [61]. The clinical 'gold standard' therapy remains the application of split thickness autologous skin grafts [52, 149, 176]. Liquid and semi-solid preparations, such as creams (e.g. silver sulphadiazine) and solutions (e.g. povidone-iodine, sodium hypochlorite), have also been used as supportive anti-infective wound care products in daily clinical practice. They are commonly used as cleaning and antimicrobial agents, allowing wound bed preparation and decontamination $[8,67]$. To extend their efficacy, facilitate their handling and improve their impact on the wound, most of these therapeutic compounds have been embedded within gauzes or incorporated within dressing materials [2, 77]. More advanced products, like traditional and modern dressings, represent a cost-effective therapy to protect the wound from the external environment and to prevent wound contamination and dehydration $[115,150]$. Due to their high water absorption rates, adhesion to the wound bed and increased pain during dressing changes, traditional dressings (e.g., gauze, cotton wool) are often employed as secondary dressings to allow the exudate drainage and to support the application of more effective products (e.g., skin substitutes) [77, 115]. Traditional dressings have been largely replaced by modern dressings, which are capable of creating and maintaining a moist environment in the wound bed, ideally suited for cellular migration and proliferation [81, 115, 124, 150, 151]. A great deal of interest has been focused on advanced dressings with the ability to release bioactive substances directly into the wound bed $[6,75,161,192]$. Bioengineered skin substitutes represent the most advanced products available for skin wounds, allowing the regeneration of both epidermal and dermal skin layers $[23,50,138,176]$. Major limitations are the permanent closure of the wound, inadequate vascularization, high manufacturing costs and lack of skin appendages [50, 149].

\section{Bioprinting technologies}

Bioprinting can be defined as the computer-aided patterning and assembling of cells, cell aggregates, biomaterials and biochemicals with a predefined spatial organization, to generate biologically relevant constructs with structural organization [45]. Contrary to bioassembly, where the minimum fabrication units are pre-formed cell building blocks, bioprinting makes use of fabrication units down to molecular level [78]. Bioprinting processes are capable of printing living and non-living materials in a computercontrolled and automated manner with high levels of resolution, accuracy and reproducibility, enabling the generation of biological substitutes with intricate architectures, 
precise geometrical configurations and biomechanical heterogeneity [16, 80, 91, 92]. Bioprinting technologies can be classified in three main categories: inkjet bioprinting, laser-assisted bioprinting and extrusion bioprinting (Table 1) $[111,125,191]$. In these processes, the material to be printed, known as bioink, is loaded in a reservoir and subsequently deposited onto a receiving substrate through the action of light, pressurized air, vibration, thermal or mechanical effects. Bioinks consist of hydrogel precursor solutions or decellularized extracellular matrix loadable with cells and/or bioactive factors that play a pivotal role on the overall reproducibility of the printing process and quality of the printed construct [100, 143, 169, 185]. Depending on the bioprinting technique, bioinks can be

Table 1 Illustration of bioprinting technologies and their main characteristics

Technology Characteristics

Inkjet bioprinting

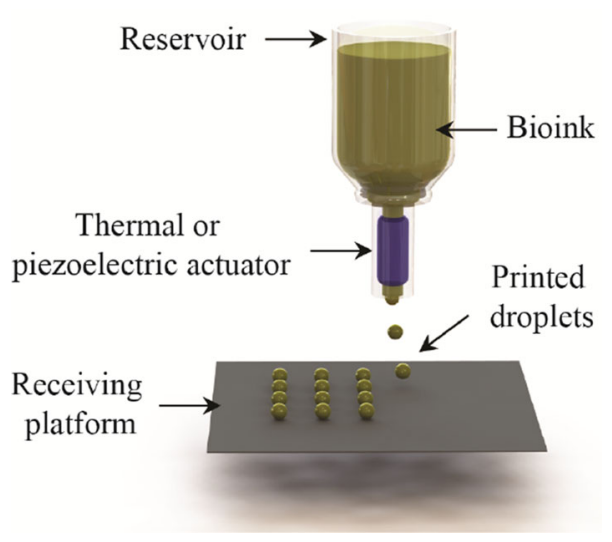

Laser-assisted bioprinting

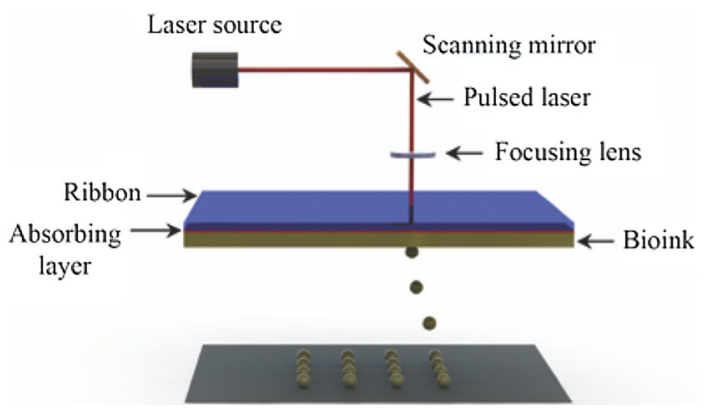

Extrusion bioprinting

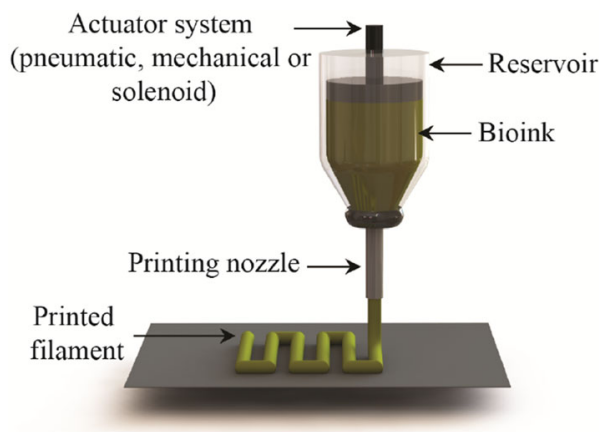

Advantages Non-contact printing; operation with multiple printheads; highthroughput; medium printing speed; low cost

Drawbacks Limited bioink viscosity; clogging issues; possibility of cell agglomeration and sedimentation

Advantages Non-contact and nozzle free printing; high cell densities and viscous inks; high resolution, reproducibility and printing speed; low to medium throughput

Drawbacks Cell-laser interaction; long printing times; difficult to generate constructs in the $\mathrm{mm}$ range; high cost and time consuming

Advantages Continuous printing of viscous bioinks and high cell densities; ability to generate 3D constructs at clinically relevant scales; easy integration with other biofabrication processes; medium throughput, resolution and cost

Drawbacks Mechanical stresses generated during the bioink deposition; difficult to produce hierarchical 3D constructs with intricate geometries 
deposited as small droplets (inkjet and laser-assisted technologies) or continuous strands of material (extrusionbased technologies), resulting in different printing times and constructs with distinct levels of heterogeneity, resolution and accuracy $[111,125]$.

\section{Inkjet bioprinting}

Inkjet is a high-throughput printing technology based on the dispensing of small drops (typically 1-100 picolitres) of a liquid bioink onto a collector substrate [170]. Drops can be generated by either continuous inkjet or drop-ondemand (DOD) inkjet printing [38]. DOD printing is the most popular method affording a rapid and fully controlled generation of droplets $(20-50 \mu \mathrm{m})$ through the application of a pressure pulse to the bioink loaded into a reservoir placed just behind the printing nozzle [29, 38, 171]. DOD printing can be further categorized according to the mechanism used for the droplet formation and ejection as thermal inkjet (vapour bubble formation) or piezoelectric inkjet (mechanical actuation). Thermal inkjet printers use a heating element to vaporize a small volume of fluid, generating a bubble that expands and ejects a controlled volume of fluid as a single droplet. The main concern associated to thermal inkjet relies on the high temperatures generated close to the heating element during the printing process, which may affect the biomolecules and cells to be printed [170, 171, 213]. However, it has been demonstrated that, due to the short duration of the heating pulses ( $\sim 2 \mu \mathrm{s}$ ), the increase in temperature of the bioink is only a few degrees, allowing the printing of viable cells with a low percentage of cell dead [35]. In piezoelectric printers, a mechanical pulse generated by the deformation of a piezoelectric transducer under a controlled voltage is used to generate and eject the liquid droplet. The printing speed, drop size and stresses experienced by the cells are easily controlled by changing the voltage applied to the piezoelectric transducer [38, 171].

Inkjet bioprinting is widely explored in the field of tissue engineering due to their unique characteristics of noncontact printing, high-throughput efficiency, automation, versatility, resolution, and possibility of parallel printing. This technology has been used to print a variety of compounds in prescribed 2D patterns, including growth factors [119], proteins [5], polymers [85], nanoparticles [190] and drugs [94]. The capability of inkjet bioprinting to print mammalian cells with high accuracy, and little or even no reduction of cell viability, was also demonstrated using different cell types, such as embryonic rat motoneurons [206], human microvascular endothelial cells [34], mouse embryonic fibroblasts [194], and retinal ganglion cells [12]. The formation of transient pores in the cell membrane has been observed during inkjet printing, which were reported as self-repaired in $2 \mathrm{~h}$ subsequent to printing [35]. The formation of transient pores seems to be associated to temporary changes in the cell membrane permeability, and was further explored to transfect cells by co-printing plasmids encoding green fluorescent protein with porcine aortic endothelial cells [207]. Despite these attractive capabilities, inkjet bioprinting is a nozzle-based technology, requiring the use of bioinks with low viscosity (typically below $\left.20 \mathrm{mPa} \mathrm{s}^{-1}\right)$ and low cell density $\left(<10^{6}\right.$ cells $\left.\mathrm{ml}^{-1}\right)$ to prevent nozzle clogging [76, 111, 125]. Printing bioinks with those characteristics is usually associated with droplet spreading and diffusion onto the substrate, which significantly reduces the spot resolution and limits the biofabrication of true 3D constructs due to the lack of structural stability of printed layers to support subsequent layers. The surface tension of the bioink and the wettability of the receiving substrate are also two key properties affecting the bioink ejection from the reservoir and the resolution of the printed constructs [38, 140, 170]. Another important limitation of inkjet printing relies on the need for bioinks capable of preventing cell settling, sedimentation and aggregation during printing in order to prevent nozzle clogging and time-consuming intermediate re-suspending operations. To address these complications, alternative methods (e.g., addition of surfactants and ethylene diamine tetra-acetic acid) have been tested to improve the stability of bioinks, to maintain their cell-suspending ability, and to enhance the homogenization, without compromising printability and biocompatibility [29, 141].

\section{Laser-assisted bioprinting}

The working principle of laser-assisted bioprinting is based on the conventional laser-induced forward transfer (LIFT) technology, involving the use of a focused laser pulse to induce the transfer of a bioink from a donor ribbon onto a collector slide [128]. For tissue engineering applications, traditional LIFT apparatus has been modified mostly regarding the print ribbon and receiving substrate in order to improve the compatibility with biological materials. The bioink is coated onto the bottom side of the laser transparent substrate and consists in cells suspended in a liquid medium or in a viscous polymer solution [57, 58, 134]. A high-powered laser pulse (usually a near infra-red laser) is focused onto a thin metal layer (1-100 nm), placed above the laser transparent substrate, generating a high-pressure bubble that propels the material towards a parallel substrate [14, 57, 128]. The most widely used modified-LITF processes in biofabrication comprise matrix-assisted pulsed laser evaporation direct writing (MAPLE DW) and absorbing film-assisted laser-induced forward transfer with its variants such as the biological laser processing (BioLP). The distinctive feature between such processes is the 
inclusion of either an optical absorbing material (MAPLE DW) or a sacrificial absorbing layer (BioLP) at the interface between the laser-transparent ribbon and the material to be transferred [128, 163]. In BioLP, the laser absorption interlayer, usually a thin metal coating ( $\mathrm{Au}, \mathrm{Ag}, \mathrm{Ti}, \mathrm{TiO}_{2}$ $\sim 100 \mathrm{~nm}$ ), displays several functions, such as: (1) eliminate the interaction between the laser and the biological material, (2) protect cells from light exposure, (3) minimize the bioink heating, (4) promote a quick thermal expansion with a more efficient droplet ejection, and (5) increase the printing reproducibility [14, 57, 128, 165].

Laser-assisted bioprinting processes are attractive for cell printing applications due to their high-resolution (10-100 $\mu \mathrm{m})$, reproducibility, nozzle-free nature and possibility of printing multiple biomaterials and cell types by incorporating those compounds in the same ribbon or having multiple parallel ribbons [111]. As a result, these processes are promising as they allow the combination of biomaterials and cells in 3D environments, enabling the formation of close cell-cell and cell-matrix interactions. In contrast to inkjet, laser-assisted bioprinting enables the processing of bioinks with a broad range of viscosities (1-300 $\left.\mathrm{mPa} \mathrm{s}^{-1}\right)$ and higher cell concentrations $\left(10^{8}\right.$ cells $\mathrm{mL}^{-1}$ ) [59, 89, 125, 165], which is a prime requisite to mimic the native organization of human tissues. Although the absence of an orifice reduces the stresses to which cells are subjected, cell injury and dysfunctionality may occur due to thermal heating, optical irradiation and mechanical impact with the receiving substrate [57, 128, 165]. Previous research has shown that these effects can be significantly reduced, or even eliminated, by controlling the laser pulse characteristics, the bioink viscosity, the thickness of absorbing layer and the substrate properties [27, 53, 101]. These parameters can also be optimized in order to better control the printing process and improve the reproducibility and resolution [54]. Laser-assisted bioprinting also enables a great control over the droplet size and number of printed cells per droplet via manipulation of the laser pulse energy, the laser spot size, the distance between the ribbon and the substrate, and the thickness of both energy absorbing layer and cell support layer [53, 57, 59, 89]. Several works have also shown the ability of laser-assisted bioprinting to print mammalian cells without affecting their viability or function, or inducing DNA damage $[14,53,55,58,60,89,90,200,203]$.

\section{Extrusion bioprinting}

The direct extrusion of bioinks onto a substrate is the most widely explored technique to produce complex and heterogeneous $3 \mathrm{D}$ constructs for tissue engineering. In this versatile technology, cell-laden polymeric solutions [28, 154], decellularized ECM components [73], cell suspensions [68], microcarriers [162] or tissue spheroids [185] are loaded into standard disposable syringes, and printed onto a building platform driven by pneumatic (pressurized air), mechanical (piston or screw) or solenoid (electrical pulses)-based dispensing systems [76, 111, 125, 137]. An important advantage of extrusion bioprinting is the ability to print highly viscous polymer solutions containing a wide range of cell densities (up $10^{7}$ cells $\mathrm{mL}^{-1}$ ) [92, 182]. It also enables the biofabrication of clinically relevant $3 \mathrm{D}$ constructs by the deposition of continuous and larger hydrogel strands through a nozzle with variable diameters, usually in a range of 150-300 $\mu \mathrm{m}$ [92, 111, 125]. The extrusion bioprinting apparatus typically includes a computer-controlled robotic stage, multiple dispensing systems, and a construction platform that collects the printed material. To further improve its versatility and the range of processable biomaterials, additional modules can also be coupled and integrated to the traditional apparatus, serving multiple purposes such as controlling the temperature of reservoirs [93], enabling multimaterial printing [105], and allowing the in situ crosslinking through physical [3] or chemical [16] methods.

Major concerns with extrusion bioprinting are related to (1) the low printing resolution $(\sim 200 \mu \mathrm{m})$, (2) the compromise between the shape fidelity and cell compatibility, and (3) the shear stresses generated during the passage of cells through the needle $[111,125]$. The printing resolution mainly depends on the device characteristics (e.g., nozzle diameter, flow rate, and printing speed), the material properties (e.g., rheological behaviour, wettability, surface tension) and the cell density. Environmental conditions and crosslinking methods also have a critical role on the achievable resolution [17, 31, 32, 111]. Since extrusion bioprinting involves the deposition of cellular bioinks through a small nozzle, printed cells are subjected to mechanical stresses during the process, which may lead to a loss of cell viability and even to alterations in the phenotype [17]. Several works showed that stresses transmitted to the cells are a function of the dispensing nozzle characteristics (geometry, diameter and length), applied pressure, deposition speed, and bioink rheological properties. These studies also demonstrated the possibility to determine and to reduce the shear stresses transmitted to the cells through experimental and numerical studies $[17,19,30,46,127]$. To address the unique requirements of extrusion bioprinting regarding the print fidelity and biological characteristics, research efforts have been focused on the development of bioinks exhibiting appropriate rheological, mechanical and biological properties [28, 32, 74, 82, 100, 152, 169, 174]. A multitude of crosslinking mechanisms, including thermal gelation, ionic and photocrosslinking, have also been explored to induce 
the in situ gelation of printed materials with the ultimate goal of improving the mechanical properties, the shape fidelity and the formation of interconnected 3D pores throughout the construct $[4,28,107]$, which still remains a major challenge.

\section{Bioprinted cellularized skin hydrogels: from in vitro to in situ printing}

The interest in bioprinting technologies to produce cellladen constructs for skin applications has been significantly increasing mainly due to their ability to pattern heterogeneous cell populations, soluble factors and biomaterials in predesigned 3D locations with high degree of automation and reproducibility. These features provide new possibilities in the development of biomimetic constructs resembling the anatomical and cellular organization of skin tissue (Fig. 2) [90,95], with potential to address the limitations of current clinical therapies, including the vascularization, regeneration of skin appendages and integration with the host tissue [52, 149]. Bioprinting processes also enable the integration with medical imaging techniques (e.g., microcomputed tomography, magnetic resonance imaging) and path-planning devices, allowing the design of patient specific implants for direct printing either in vitro or in situ $[184,200]$.

\section{Requirements of printed skin}

Printed skin constructs are currently explored for several purposes including wound healing and in vitro models for pharmaceutical testing and disease model (e.g., inflammatory skin disease). Advances in microfluidic and bioprinting technologies have also allowed the miniaturization of skin models through the development of skin-on-a-chip devices, which offer a valuable alternative to animal experimentation [122]. In order to closely reproduce the main properties of native skin and provide reliable models for clinical translation, printed skin must fulfil key compositional and functional characteristics:

- Cellular composition: native skin is composed of multiple layers containing distinct cellular populations. The epidermal layer contains keratinocytes, melanocytes, Merkel and Langerhans cells. In the dermis, fibroblasts are the predominant cells, while the hypodermis is composed of adipocytes. To replicate as close as possible the heterogeneous cellular composition of native skin, each cell type should be precisely dispensed at specific 3D locations in their respective layer. The density and ratio between cell populations within the construct must be controlled in order to promote cell-cell interactions that regulate autocrine and paracrine signalling.

- Biochemical composition: in the dermal region, cells are embedded within a rich ECM that provides a multitude of cell-adhesion and cell-remodelling sites, allowing cells to remodel and interact with the surrounding matrix. The basement membrane physically separates skin layers, providing motifs for cell anchorage, which is essential for stabilization and diffusion of molecules. In printed skin, the biochemical cues, their function, location and density must be precisely controlled. The presence of cell-adhesion sites and cell-proteolytic domains is fundamental to replicate the dynamic and interactive nature of ECM. Also the ability to sequester and release bioactive molecules, for instance via growth factor-binding domains, is of paramount importance for the sustained release of cytokines and growth factors during the wound healing.

- Zonal organization and material composition: native skin is a highly complex tissue composed of a multitude of ECM components, which composition and ratio varies according to the region. The dermal layer is rich in collagens (I, III, IV, VII), fibronectin and glycosaminoglycans. Dermis is also organized into an upper 'papillary' (high ratio of collagen type III to type I) and a lower 'reticular' (low ratio of collagen type III to type I) region [187]. At the epidermal-dermal junction, a basement membrane mostly composed of laminin and collagen IV provides a physical barrier between two layers [15]. Materials for skin printing should consider the fibrillar and hydrated nature of ECM. Although is difficult to develop a formulation containing all the skin components, it's fundamental to engineer advanced materials which stiffness and composition could be readily altered according to the location throughout the construct. The design of materials able to mimic the basement membrane constitutes an important requisite in printed skin.

- Tissue architecture and shape: skin has thickness in a range of 1.0-2.5 mm, depending on the location in the body, with epidermis measuring approximately $0.2 \mathrm{~mm}$ [196]. The thin papillary region contains higher cellular density along randomly orientated collagen fibre bundles, while the thicker reticular dermis consists of highly orientated fibre bundles. The heterogeneity of skin throughout the body requires precise control over the layer thickness in order to print constructs matching the wound depth. In addition, the thickness and fibre orientation in both papillary and reticular dermis should be considered to improve biomimicry. The shape of the printed construct should also be defined according to the specific application. 


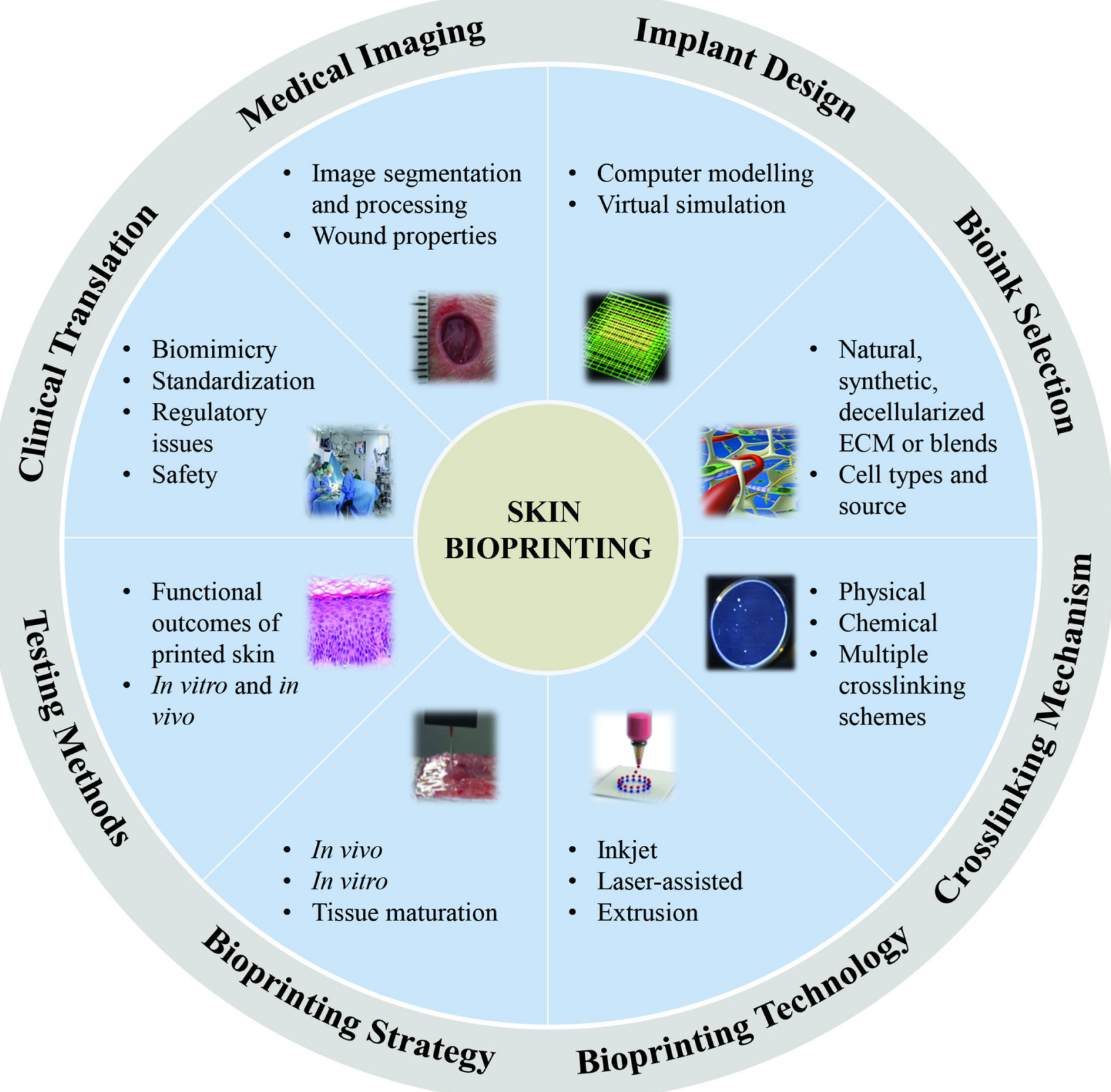

Fig. 2 Illustration of the multidisciplinary tasks involved in the design of 3D constructs for skin repair and regeneration using bioprinting technologies

- Barrier function: epidermis contains keratinocytes at different stages of differentiation with fully stratified keratinocyte layers providing an efficient barrier to the penetration of external agents across the skin. Lamellar granules, produced by keratinocytes, secret several key compounds (lipids, proteins, hydrolytic enzymes) for skin barrier properties [13]. To recreate the barrier properties of skin, printed constructs must contain an epidermal region consisting of densely packed keratinocytes. Constructs need to be cultured at air-liquid interface (ALI) to promote stratification and the barrier properties carefully evaluated. Late or incomplete stratification and keratinization of printed constructs must be evaluated, in particular, when immortalized keratinocyte cells are used.

- Appendages and pigmentation: skin contains adnexal structures such as nails, hair follicles, sweat, apocrine and sebaceous glands. Melanocytes produce melanin, a pigment that confers coloration to the skin and protects from UV light. Merkel and Langerhans cells participate 
in sensing and immunological defence, respectively. The development of skin appendages in printed skin is a major challenge in the field. Skin pigmentation can be addressed by printing melanocytes in the epidermis, while sweat glands can be engineered by printing epidermal-derived stem/progenitor cells.

- Vascularization: dermis contains numerous blood vessels that provide nutritional support to the skin. Vasculature includes larger blood vessels at the interface between the reticular dermis and hypodermis, which branch into small vessels to supply superficial plexus at the junction between the papillary and reticular dermis, as well as the epidermis by diffusion. The ability to engineer functional vasculature in $3 \mathrm{D}$ is critical for nutrient supply throughout thick skin constructs. Printing branched, perfusable channels could be a viable solution to promote efficient mass transfer of the skin. Complementary strategies could also involve the co-printing of stromal and endothelial cells as well as the tethering and release of angiogenic factors.

\section{Hydrogel bioinks}

Hydrogels are the golden standard materials for skin regeneration as they provide a hydrated and highly permeable microenvironment in which, depending on the composition (e.g., cell-adhesion and proteolytically sensitive motifs) and properties (e.g., stiffness), encapsulated cells might migrate and proliferate in a similar way to what happens in the native ECM [111]. Hydrogels have been widely used to assist the regenerative and reparative processes of many tissues [41, 198, 199] and several studies were performed assessing their potential as wound healing adjuvant, mainly due to their porosity, permeability, viscoelastic properties and low immunogenicity (depending on the source) [21, 39, 64, 114]. Hydrogels are defined as crosslinked 3D network structures obtained from a range of synthetic or natural polymers that can absorb and retain large amounts of water $[7,168]$. They are usually classified according to the nature of the crosslinks established between the polymer chains into chemical or physical hydrogels. Chemical hydrogels involve the formation of covalent bonds, while physical hydrogels are obtained when physical interactions are established between the polymeric chains (molecular entanglement, ionic interaction and hydrogen bonding) [168, 210]. Hydrogels display many of the desired characteristics of an ideal skin substitute, as they promote wound debridement, while providing a suitable moist environment to stimulate the healing process. In addition, they can absorb wound exudates, allow gaseous exchanges and prevent bacterial invasion. Hydrogels also provide thermal isolation and display low adherence to the wound bed, which facilitates dressing change without trauma to the patient. Furthermore, the fine-tuning of hydrogel properties is easy to achieve, allowing control over stiffness, biodegradability rates and permeability to either cells or soluble factors. Transparent hydrogels allow to follow-up the wound healing process without removal. When carrying cells, either fibroblasts or keratinocytes separately [106] or together [70], these hydrogels have shown better performance in wound healing and host tissue integration.

A major challenge in skin bioprinting, is designing suitable bioinks to produce 3D cellular constructs with intricate geometries, shape fidelity, and high resolution in the placement of cells. In the biofabrication field, traditional approaches to generate such constructs often involve (1) the sequential printing of cell-laden hydrogels or melt extruded thermoplastic fibres, (2) the formulation of viscous bioinks by adding high molecular weight polymers (e.g., hyaluronic acid, HA), or (3) the use of increased polymer concentrations and crosslinking densities $[152,173,174,193]$. The combination of hydrogel bioprinting with melt extrusion has been successfully explored to design well-defined 3D constructs with improved mechanical properties, which is of special interest for load bearing tissues [80], but of limited application in soft tissues. The printing process of viscous bioinks might affect the distribution of cells throughout the construct ultimately leading to tissue heterogeneity, while highly crosslinked hydrogels may lead to excessively stiff matrices that impose severe restrictions to cell spreading, migration and proliferation [11, 24, 130]. Thus, it is crucial to ensure that the bioink has the appropriate rheological properties to be printed and, at the same time, is able to maintain the shape upon deposition. Alternative strategies have been tested to improve the printing fidelity without compromising the bioink cytocompability, including the printing of partially crosslinked hydrogels, the crosslinking of hydrogel solutions during bioprinting, and the deposition of biocompatible sacrificial materials that provide initial support for the printed hydrogel pattern $[43,135]$.

The development of hydrogels to be applied as a bioink is a complex and multidisciplinary process that requires knowledge about the principles of printing mechanisms and the fluid properties required for a given liquid to be printable. The interactions between the bioink and the receiving substrate as well as its rheological properties are important parameters determining the resolution and accuracy of printed constructs $[38,57,76,111,123]$. In order to adapt a material for bioprinting technologies, it is important to take into account whether the technical characteristics of the printing device afford the design of biologically relevant constructs for a given application. By 
placing suitable cell types in appropriate positions, the tissue construct may then mature into a tissue/organ and late achieve functionality either inside a bioreactor or in vivo [22]. The ideal properties of hydrogels for bioprinting include stability, sterilization, biodegradability, adequate mechanical properties and swelling characteristics, but it is also required that both hydrogel chemistry and crosslinking mechanisms promote cell function [126]. Cells must not only survive to the printing process and remain viable, but should also be able to migrate within and from the implant, proliferate, establish cell-cell/cellmatrix interactions, and also secrete growth factors and other healing mediatiors. In addition to these important general considerations, the properties of bioinks should adapt to the printing mechanism used to produce tissue constructs. For extrusion bioprinting, in which the bioink flows through a nozzle towards the substrate, rheological properties are particularly relevant. The rheological behaviour of bioink determines how the viscosity is affected during the printing as a response to the shear stress. Printing cells embedded in a hydrogel precursor solution also requires careful selection of the viscosity in order to ensure homogenous distribution of cells and prevent nozzle clogging. This is particularly critical for inkjet printing owing the limited range of admissible viscosities [38]. In addition to viscosity, surface energy, tension and charge constitute other relevant properties of biomaterials for bioprinting, as they exert great influence on droplet formation and ejection [57, 123]. Moreover, the bioink should also undergo a fast and cytocompatible gelation after deposition in order to maintain the prescribed shape and spatial location of cells at high resolution.

Despite recent advances in the design of printable bioinks for various applications (Table 2), the number of bioinks for bioprinting cellular skin substitutes is still limited to a restricted number of natural hydrogels including alginate, collagen, gelatin, fibrin and hyaluronic acid. The interest in these materials mainly relies on the fact that their composition and structure resembles the ECM properties of native tissues [26]. These polymers can also be easily converted into either physical or chemical hydrogels under cell-compatible conditions through a myriad of crosslinking pathways [210]. In addition, certain natural polymers (e.g., collagen) also present cell-proteolytic domains and/or adhesion motifs, providing recognition sites for embedded cells and allowing the cellmediated degradation of the hydrogel network in a similar way to the remodelling of native ECM. Natural hydrogels, in particular protein-derived hydrogels, usually present concerns regarding weak mechanical properties, high immunogenicity and virus/disease transmission, though they retain their biological activity being the most widely used ECM-mimicking materials [47, 147]. Synthetic hydrogels constitute an important alternative due to their controlled chemical composition and tuneable mechanical properties. The drawback of most synthetic materials is the lack of cell-adhesion moieties, which can be solved by the incorporation of cell instructive cues into the polymer backbone [108].

\section{Printed skin constructs for wound healing}

A major application of printed skin constructs is to promote the wound repair and regeneration. Functional skin is an important need in medical field to treat patients with a variety of injuries, including (1) burn wounds, which lack of the skin barrier and are more susceptible to infection, (2) chronic ulcers, which are difficult to heal and associated to high healthcare costs, and (3) scars, which cause severe anaesthetic limitations and movement disabilities. In response to these needs, bioprinting has been explored to create sophisticated bi-layered skin substitutes containing dermal and epidermal components, which mimic the native organization of skin tissue.

Michael et al. [117] used the laser-assisted bioprinting to produce multi-layered cellular skin constructs and evaluate their ability to promote the in vivo regeneration of fullthickness skin wounds in nude mice (Fig. 3). Skin substitutes were created by printing 20 layers of NIH3T3 fibroblasts followed by 20 layers of HaCaT keratinocytes suspended in collagen onto a sheet of Matriderm ${ }^{\mathrm{TM}}$ and subsequently incubated under submerged conditions overnight. In vitro studies showed that fibroblasts started to produce collagen and keratinocytes formed a dense epidermis, though no differentiation was observed. After 11 days of in vivo implantation, skin substitutes showed a good integration into the native tissue. Small blood vessels were also detected in the printed skin substitutes, growing from both the wound bed and wound edges into the Matriderm ${ }^{\circledR}$ towards the direction of printed cells. Immunohistochemistry assays confirmed the presence of E-cadherin between keratinocytes, indicating the establishment of cell-cell contacts. This work demonstrated the capability of laser-assisted bioprinting to produce 3D biological skin substitutes capable of developing functional tissues in vitro and promote skin regeneration in vivo, which represents an exciting advance in the field of 3D skin bioprinting.

Rather than printing 3D skin constructs in vitro for subsequent implantation, efforts have also been focused on the development of integrated bioprinting strategies for the in situ printing of cellular skin substitutes. In situ skin printing is challenging as it requires the development of dedicated bioprinting devices, the integration with imaging systems to obtain data from the wound site, and the design of bioinks capable of instructing printed cells to perform 
Table 2 Examples of bioinks used in 3D bioprinting

\begin{tabular}{|c|c|c|c|c|c|c|}
\hline Bioink & Composition & Crosslinking method & Cell type & $\begin{array}{l}\text { Bioprinting } \\
\text { technology }\end{array}$ & Application & References \\
\hline \multicolumn{7}{|l|}{ Natural origin } \\
\hline \multirow[t]{5}{*}{ Alginate } & Alginate & Ionic $(\mathrm{Ca})$ & bMSC & Extrusion & Bone & {$[46]$} \\
\hline & Oxidized alginate & Ionic $(\mathrm{Ca})$ & hASC & Extrusion & n.s. & [74] \\
\hline & Alginate and GelMA & $\begin{array}{l}\text { Ionic }(\mathrm{Ca}) \text { and } \\
\text { chemical (UV) }\end{array}$ & HUVEC & Extrusion & Cardiac & {$[33]$} \\
\hline & Alginate, gelatin and HAp & $\begin{array}{l}\text { Thermal and ionic } \\
\text { (Ca) }\end{array}$ & hMSC & Extrusion & Bone & [204] \\
\hline & $\begin{array}{l}\text { Alginate, carboxymethyl- } \\
\text { chitosan, and agarose }\end{array}$ & Ionic (Ca) & HNSC & Extrusion & Neural & {$[56]$} \\
\hline Cellulose & $\begin{array}{l}\text { Nanofibrillated cellulose and } \\
\text { alginate }\end{array}$ & Ionic $(\mathrm{Ca})$ & Chondrocytes & Extrusion & Cartilage & [112] \\
\hline \multirow[t]{4}{*}{ Collagen } & Collagen & Physical & $\begin{array}{c}\text { Fibroblasts and } \\
\text { keratinocytes }\end{array}$ & BioLP & Skin & {$[90,117]$} \\
\hline & $\begin{array}{l}\text { Cell-laden collagen (core) and } \\
\text { alginate (sheat) }\end{array}$ & Ionic $(\mathrm{Ca})$ for alginate & hASC & $\begin{array}{l}\text { Extrusion } \\
\text { with core } \\
\text { sheath } \\
\text { nozzle }\end{array}$ & n.s. & [211] \\
\hline & Collagen and fibrinogen & Physical (thrombin) & Chondrocytes & Inkjet & Cartilage & [208] \\
\hline & Collagen and fibrinogen & Physical (thrombin) & AFS or MSC & Inkjet & Skin & [184] \\
\hline \multirow{3}{*}{$\begin{array}{l}\text { Decellularized } \\
\text { ECM }\end{array}$} & Decellularized heart tissue & Chemical (UV) & Cardiomyocytes & Extrusion & Cardiac & [73] \\
\hline & Decellularized adipose tissue & Thermal & hASC & Extrusion & $\begin{array}{l}\text { Adipose } \\
\text { tissue }\end{array}$ & {$[144]$} \\
\hline & $\begin{array}{l}\text { Decellularized adipose, } \\
\text { cartilage and heart tissue }\end{array}$ & Thermal & $\begin{array}{l}\text { hASC, hTMSC } \\
\text { and rat } \\
\text { myoblast cells }\end{array}$ & Extrusion & n.s. & {$[143]$} \\
\hline Dextran & Methacrylated dextran and HA & Chemical (UV) & Chondrocytes & Extrusion & n.s. & [152] \\
\hline DNA & $\begin{array}{l}\text { Polypeptide-DNAconjugate } \\
\text { and complementary DNA } \\
\text { linker }\end{array}$ & DNA hybridization & $\begin{array}{l}\text { AtT-20 and } \\
\text { HEK-293 } \\
\text { cells }\end{array}$ & $\begin{array}{l}\text { Extrusion } \\
\text { (microvalve- } \\
\text { based) }\end{array}$ & n.s. & {$[100]$} \\
\hline \multirow[t]{5}{*}{ Gelatin } & Gelatin & $\begin{array}{l}\text { Enzymatic (microbial } \\
\text { transglutaminase) }\end{array}$ & $\begin{array}{l}\text { HUVECs and } \\
\text { HEK293 cells }\end{array}$ & Extrusion & n.s. & {$[72]$} \\
\hline & Gelatin and fibrinogen & $\begin{array}{l}\text { Thermal and } \\
\text { enzymatic (thrombin } \\
\text { and } \\
\text { transglutaminase) }\end{array}$ & $\begin{array}{l}\text { hMSCs, hNDFs } \\
\text { and HUVECs }\end{array}$ & Extrusion & Vascular & {$[92]$} \\
\hline & $\begin{array}{l}\text { Gelatin, alginate, dermal } \\
\text { homogenates and EGF }\end{array}$ & $\begin{array}{l}\text { Thermal and ionic } \\
\text { (Ca) }\end{array}$ & $\begin{array}{l}\text { Epithelial } \\
\text { progenitor } \\
\text { cells }\end{array}$ & Extrusion & $\begin{array}{l}\text { Sweat } \\
\text { gland }\end{array}$ & {$[69]$} \\
\hline & GelMA & Chemical (UV) & HepG2 & Extrusion & n.s. & [17] \\
\hline & $\begin{array}{l}\text { Methacrylated and acetylated } \\
\text { gelatin }\end{array}$ & Chemical (UV) & Chondrocytes & Inkjet & n.s. & {$[65]$} \\
\hline Gellan gum & $\begin{array}{l}\text { Gellan gum, alginate HAp } \\
\text { particles }\end{array}$ & Ionic & Chondrocytes & Extrusion & Cartilage & [83] \\
\hline \multirow[t]{4}{*}{ Hyaluronic acid } & HA-pNIPAAM and HAMA & $\begin{array}{l}\text { Thermal and chemical } \\
\text { (UV) }\end{array}$ & Chondrocytes & Extrusion & Cartilage & {$[82]$} \\
\hline & HAMA and GelMA & Chemical (UV) & HAVIC & Extrusion & Cardiac & {$[42]$} \\
\hline & $\begin{array}{l}\text { Thiol HA and thiol gelatin } \\
\text { with gold nanoparticles }\end{array}$ & Covalent interactions & Fibroblasts & Extrusion & n.s. & [183] \\
\hline & $\begin{array}{l}\left.\text { Thiol HA (Heprasil }{ }^{\circledR}\right) \text {, thiol } \\
\text { gelatin }\left(\text { Heprasil }^{\circledR}\right) \text {, } \\
\text { decellularized ECMs, and } \\
\text { PEG-based crosslinkers }\end{array}$ & $\begin{array}{l}\text { Chemical (Michael- } \\
\text { type addition and } \\
\text { UV) }\end{array}$ & $\begin{array}{l}\text { Cell liver } \\
\text { spheroids }\end{array}$ & Extrusion & Liver & {$[185]$} \\
\hline
\end{tabular}


Table 2 continued

\begin{tabular}{|c|c|c|c|c|c|c|}
\hline Bioink & Composition & Crosslinking method & Cell type & $\begin{array}{l}\text { Bioprinting } \\
\text { technology }\end{array}$ & Application & References \\
\hline & $\begin{array}{l}\text { Adamantane and } \beta \text { - } \\
\text { cyclodextrin modified HA }\end{array}$ & $\begin{array}{l}\text { Supramolecular } \\
\text { assembly }\end{array}$ & $\begin{array}{l}\text { MSC and 3T3 } \\
\text { fibroblasts }\end{array}$ & Extrusion & n.s. & {$[63]$} \\
\hline Matrigel $^{\mathrm{TM}}$ & $\begin{array}{l}\text { Matrigel and alginate }(3: 1) \\
\text { containing VEGF-loaded } \\
\text { gelatin microparticles }\end{array}$ & Ionic $(\mathrm{Ca})$ & hEPC & Extrusion & Bone & {$[155]$} \\
\hline $\begin{array}{l}\text { M13 bacteriophage } \\
\text { (phage) }\end{array}$ & $\begin{array}{l}\text { Genetically engineered M13 } \\
\text { phage and alginate }\end{array}$ & Ionic $(\mathrm{Ca})$ & $\begin{array}{l}\text { MC3T3-E1 } \\
\text { cells }\end{array}$ & Extrusion & Bone & [97] \\
\hline Silk & Silk fibroin and gelatin & $\begin{array}{l}\text { Enzymatic (mushroom } \\
\text { tyrosinase) and } \\
\text { physical crosslinking } \\
\text { (sonication) }\end{array}$ & hTMSC & Extrusion & n.s. & [37] \\
\hline \multicolumn{7}{|l|}{ Synthetic origin } \\
\hline \multirow[t]{2}{*}{ PEG } & PEGDMA & Chemical (UV) & Chondrocytes & $\begin{array}{l}\text { Thermal } \\
\text { Inkjet }\end{array}$ & Cartilage & {$[36]$} \\
\hline & $\begin{array}{l}\text { PEGDMA containing cell } \\
\text { adhesive and MMP sensitive } \\
\text { peptides }\end{array}$ & Chemical (UV) & hMSCs & $\begin{array}{c}\text { Thermal } \\
\text { Inkjet }\end{array}$ & Cartilage & [48] \\
\hline Pluronic & $\begin{array}{l}\text { Acrylated and non-acrylated } \\
\text { pluronic F127 and HAMA }\end{array}$ & Chemical (UV) & Chondrocytes & Extrusion & Cartilage & [118] \\
\hline
\end{tabular}

AFSC amniotic fluid-derived stem cells, $b M S C$ bone marrow stromal cells, Ca calcium, GelMA methacrylated gelatin, HAMA methacrylated hyaluronan, Hap hydroxyapatite, HA-pNIPAAM poly(N-isopropylacrylamide) grafted hyaluronan, hASCs human adipose-derived stem cells, HAVIC human aortic valvular interstitial cells, hEPCs human endothelial progenitor cells, HepG2 hepatocarcinoma cell line, hNDFs human neonatal dermal fibroblasts, HNSC human neural stem cells, hTMSCs human inferior turbinate-tissue derived mesenchymal stromal cells, hTMSCs human nasal inferior turbinate tissue-derived mesenchymal stromal cells, HUVECs human umbilical vein endothelial cells, n.s. not specified, $p(H P M A m-l a c)$ poly(N-(2-hydroxypropyl)methacrylamide lactate) functionalized with methacrylates, PEGDMA poly(ethylene) glycol dimethacrylate

their native functions. Binder et al. [18, 184] developed a device for the in situ skin printing composed of a cartridge delivery system containing a series of inkjet nozzles and a laser scanning system, both mounted on a portable XYZ plotting system. The data obtained from the laser was used to reconstruct a 3D model of the wound, which was subsequently employed to determine the skin area that was missing from the wound. Afterwards, the printheads filled the wound site with a bioink containing skin cells in a layer-by-layer manner. The potential of the system to induce the skin regeneration was firstly evaluated through the printing of human keratinocytes and fibroblasts suspended in a fibrinogen-collagen precursor solution into a full thickness skin lesions $\left(3.0 \times 2.5 \mathrm{~cm}^{2}\right)$ created on $\mathrm{nu} /$ nu mice [18]. After printing each layer, a thrombin solution was sprayed on top of the deposited layer to induce hydrogel formation. Results showed the complete closure of the wound in 3 weeks and the formation of new skin with similar properties to the native tissue. Histological analyses also revealed that the newly formed skin contained organized dermal collagen and a fully developed epidermis. The same research group used a similar procedure and bioprinting technique to print amniotic fluidderived stem cells (AFSC) and bone marrow-derived mesenchymal stem cells (MSC) suspended in a fibrinogencollagen gel into full-thickness skin wounds in mice [184]. The cell-biomaterial solution was dispensed to the skin wounds $\left(2.0 \times 2.0 \mathrm{~cm}^{2}\right)$ with uniform cell distribution. The closure and re-epithelialization of wounds treated with printed AFSC and MSC were significantly better than those of wounds treated only with the fibrin-collagen hydrogel. Histological sections of skin samples harvested 2 weeks after printing/implantation showed well-defined and organized epidermal layers of the regenerated skin in MSC and AFSC-treated wounds, which was accompanied by increased neovascularization and blood vessel maturation, particularly in the case of AFSC-treated wounds. However, findings also demonstrated that cells only remained transiently at the lesion site and did not permanently integrate with the host tissue. Another limitation of this bioprinting approach relies on the slow crosslinking time of the bioink system, which increased the overall procedure. 

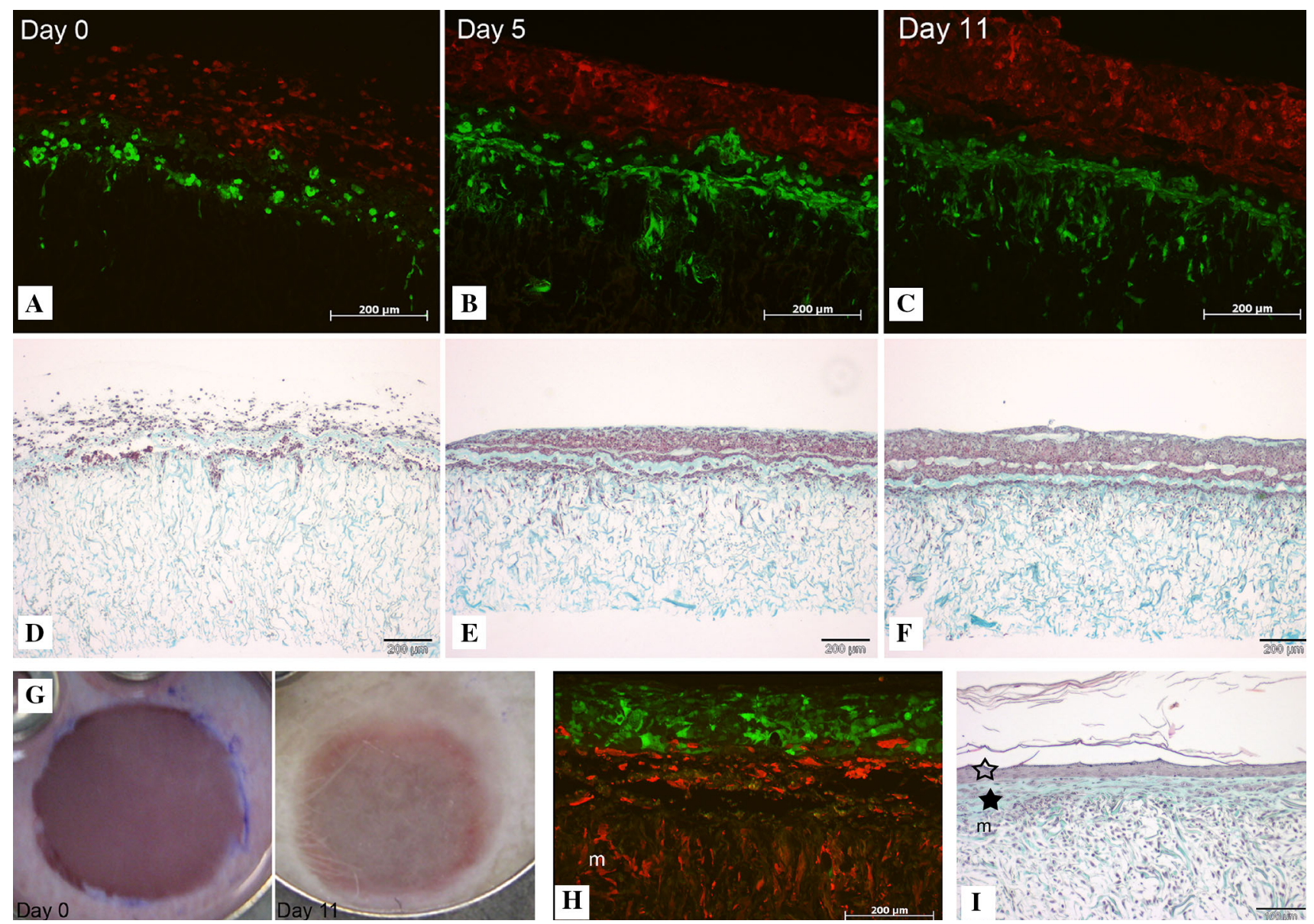

Fig. 3 Bi-layered skin substitute produced by BioLP through the printing of fibroblasts and keratinocytes and characterized after 11 days of in vitro culture at the air-liquid interface (a-f) or in vivo implantation in nude mice $(\mathbf{g}-\mathbf{i})$. a-c Fluorescent microscopy images showing the presence of red keratinocytes (HaCaT-mCherry) and green fibroblasts (NIH3T3-eGFP). d-f Masson's trichrome staining of sections containing collagen (green) and the cells (reddish), indicating the formation of a dense epidermis on day 5. G Construct in the

In addition to suitable mechanical, swelling and biodegradation characteristics, bioinks for in situ skin printing should exhibit fast crosslinking to reduce the printing time, support cell activity and eventually act as a delivery vehicle of biological factors. In order to meet such requirements, Skardal et al. [186] developed a photocrosslinkable heparin-conjugated hyaluronic acid (HAHP) hydrogel for in situ printing capable of sequestering and releasing cell secreted growth factors. The bioink system, composed of thiolated HA with conjugated heparin groups, thiolated gelatin, PEGDA cross-linker and I2959 as photoinitiator, was loaded with AFS cells and printed directly onto full thickness skin wounds $\left(2.0 \times 2.0 \mathrm{~cm}^{2}\right)$ in a nu/nu murine model (Fig. 4). After printing, the bioink was crosslinked in situ via thiol-ene photopolymerization upon exposure to UV light. In vitro tests indicated the effectiveness of heparin-mediated growth factor binding in dorsal skin fold chamber in nude mice immediately after implantation and after 11 days. $\mathbf{h}$ Fluorescence microscopy image of the construct with green fluorescence emitted by HaCaT-eGFP cells and red fluorescence emitted by fibroblasts (NIH3T3-mCherry). i Histological sections of the tissue construct stained with Masson's trichrome showing a dense epidermis (empty asterisks) and a corneal layer [117]

modulating the release of pro-angiogenic AFS-secreted FGF and VEGF from HA-HP hydrogels. Wounds treated with cell-laden HA-HP hydrogels showed slightly higher closure rate and re-epithelialization compared to both HAtreated and non-treated wounds, though the differences between groups were not statistically significant after 14 days post-printing. Histological characterization of the harvested skin tissue indicated that HA-HP hydrogels promoted higher microvessel density which may be due to the sequestration of and release of AFS cell-secreted growth factors as well as increased deposition of elastin. Although this work demonstrates the potential of photopolymerizable heparin-containing HA-based bioinks combined with AFS cells for in situ skin printing, further characterization regarding the effectiveness of this strategy on the wound healing and quality of new skin is necessary. 
A

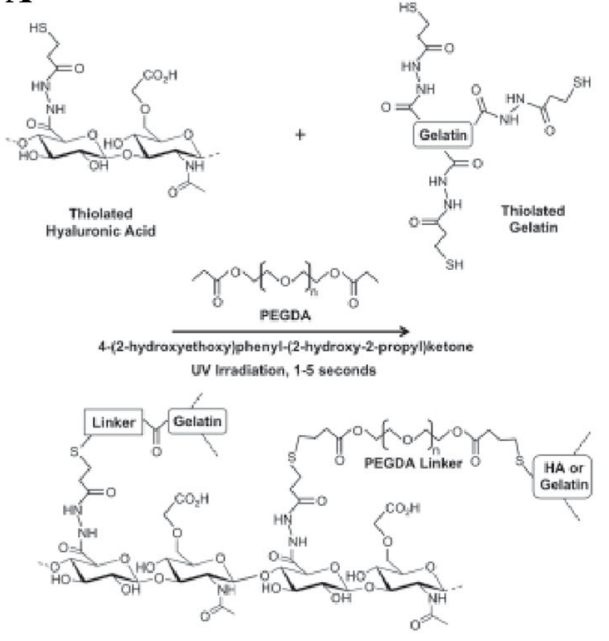

B

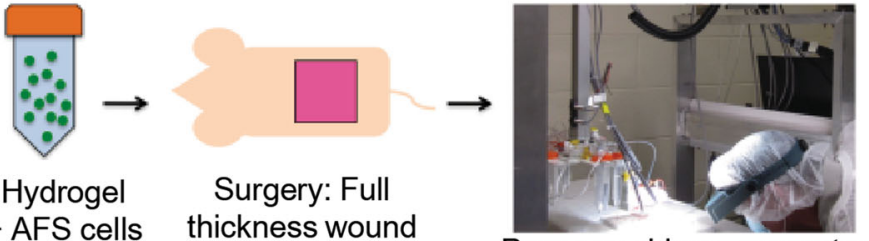

Pressure-driven, computer controlled bioprinting device

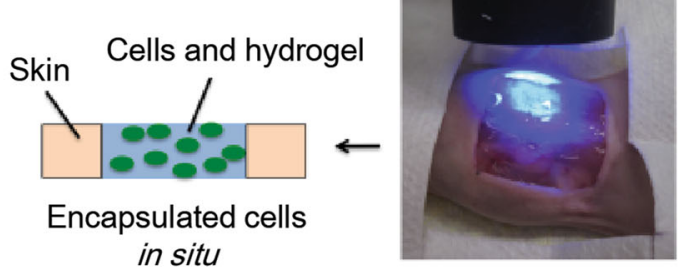

Photopolymerization

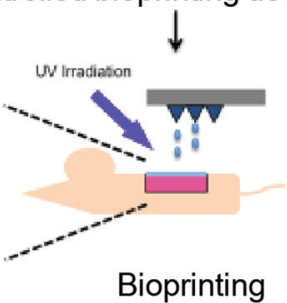

Bioprinting

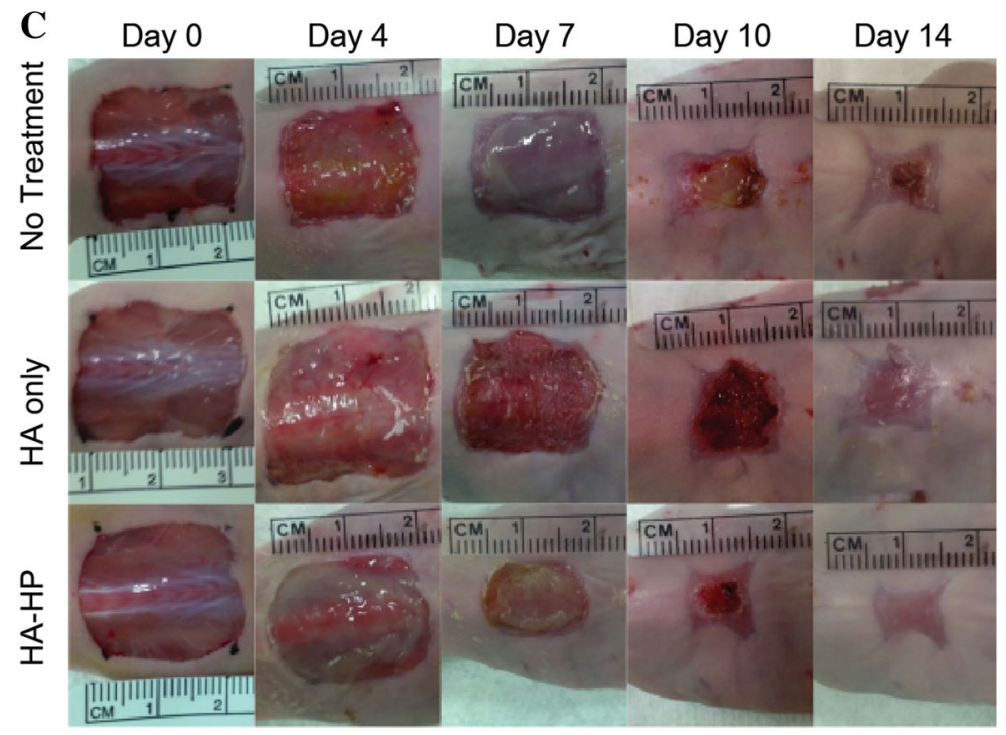

D
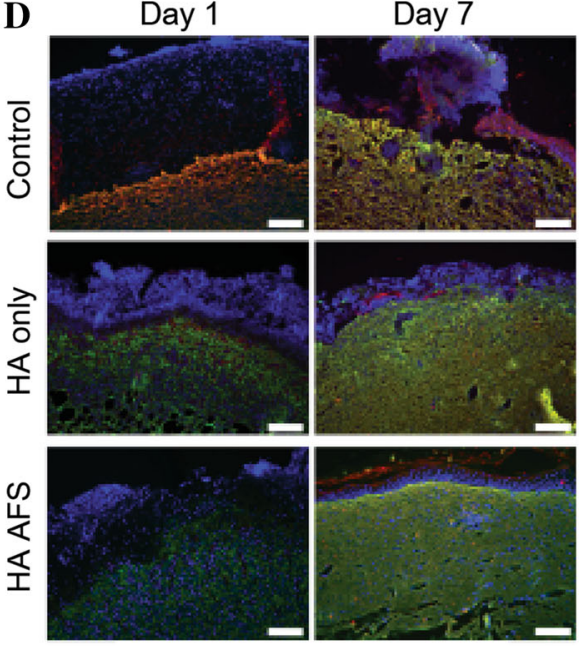

Immunohistochemistry (collagen I red, III green)
Fig. 4 In situ printing of a photocrosslinkable heparin-conjugated hyaluronic acid hydrogel system loaded with AFS cells into fullthickness skin wounds in a nu/nu murine model. a Schematic representation of UV light photoinitiated thiol-ene polymerization of the hydrogel system. b Illustration of the in situ printing strategy.

\section{Printed skin constructs as in vitro models}

The interest in printing in vitro human skin models as platforms for toxicity and efficacy testing of topical medications and cosmetics has been significantly increasing due to the need for cost-effective alternatives to animal experimentation. Although there are several works demonstrating the printing of bi-layered skin constructs and evaluating their properties $[156,164]$, there is a lack of studies using and testing their applicability for pharmaceutical or cosmetic testing. The majority of these studies employ skin equivalents exclusively created by manual methods $[160,205]$ or fabricated using c Macroscopic images of the wounds over the study, showing enhanced closure of wounds treated with the hydrogel system compared to the control groups. d Immunohistochemistry analysis of tissue sections stained for collagen type I (red), collagen type III (green), and DAPI (blue) [186]

components obtained through 3D printing technologies combined with manual deposition of cell-laden solutions [122].

Lee et al. [93] used a robotic cell dispensing technology composed of a set of electromechanical microvalves to fabricate $3 \mathrm{D}$ cell-laden constructs in vitro mimicking the native skin anatomy (Fig. 5). Their approach involved the printing of collagen hydrogel precursor solutions, keratinocytes and fibroblasts suspension, followed by the crosslinking of each printed layer using a nebulized sodium bicarbonate solution as a gelation agent. Results indicated no significant differences on the viability of printed cells compared to manually plated cells, while confocal 

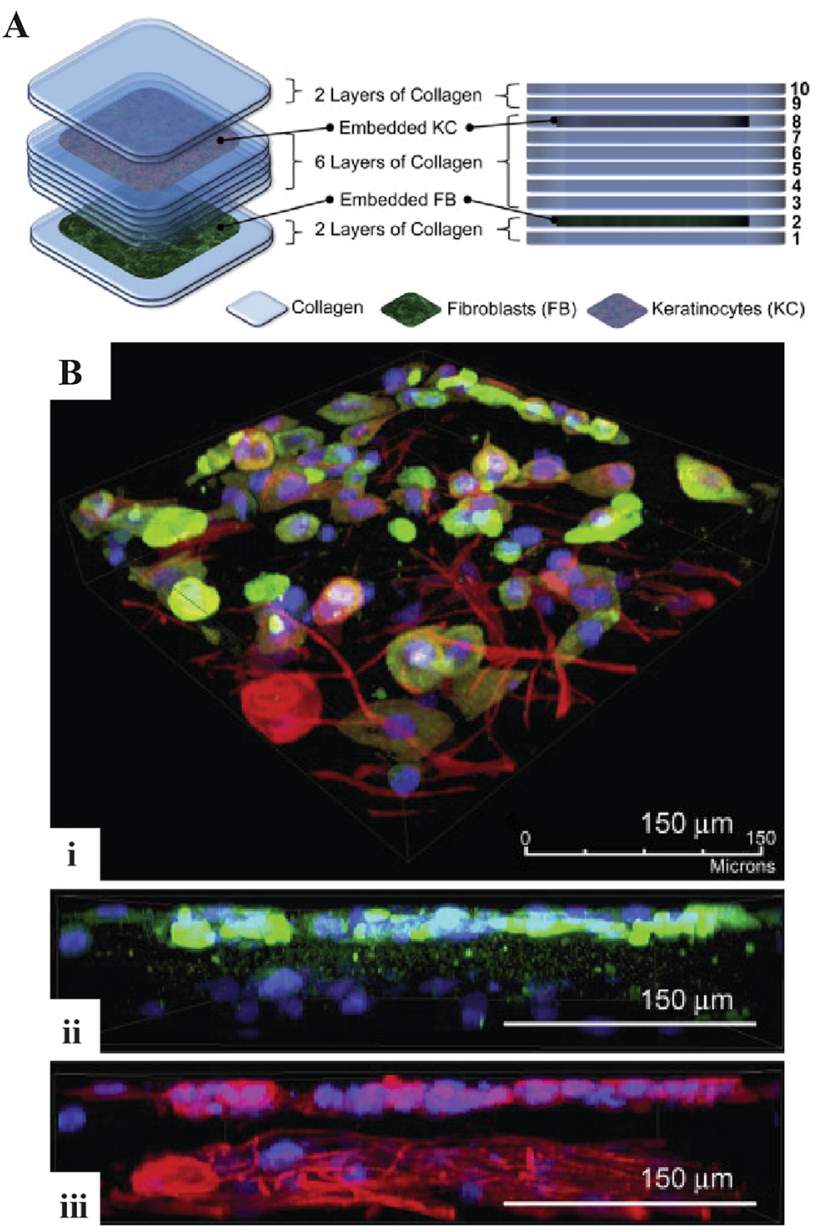

Fig. 5 a Schematic illustration of bioprinting strategy and composition of skin constructs. b immunofluorescent images of multilayered skin constructs (bi) showing keratin-containing $\mathrm{KC}$ layer (bii) and $\beta$-tublin-containing $\mathrm{KC}$ and FB (biii) [93]

microscope images of printed 3D constructs after 4 days of in vitro culture showed distinct layers of fibroblasts and keratinocytes. This strategy was further explored and optimized in another work from the same group, where particular attention was given to the optimization of printing parameters, cell densities and histological characterization of skin constructs [95]. Printed multi-layered constructs were cultured under submerged conditions followed by exposure to the air-liquid interface to stimulate proliferation of keratinocytes. At day 14, printed constructs exhibited a dense epidermal layer and a sparsely populated dermal layer without cell invasion and migration across the two regions. Histological analysis revealed epidermis compaction along the period of ALI culture, accompanied by the formation of terminally differentiated stratum corneum and thigh junctions between keratinocytes. Printed constructs maintained the shape and dimensions without shrinkage during the culture period, while conventional constructs obtained by manual deposition presented continuous shrinkage and shape modification. Further improvements on the density of fibroblasts in the dermis, as well as on the stratification and keratinization, are required to better mimic the native skin tissue. In another work, laser-assisted bioprinting was explored to produce 3D skin grafts consisting of a collagen matrix containing fibroblasts and keratinocytes in two main regions, aiming at mimicking the anatomic organization of native skin [90]. The bi-layered 3D skin substitute was created by printing 20 layers of fibroblasts followed by 20 layers of keratinocytes. Both cell types were embedded in a collagen matrix and transferred onto a receiving slide coated with Matriderm ${ }^{\mathrm{TM}}$ (composed of collagen and elastin). After 10 days of in vitro culture, cells remained viable and located at the printed positions, without mixing between fibroblasts and keratinocytes. Immunohistochemical analyses revealed the formation of a laminin layer (main protein in basement membrane) between the fibroblasts and keratinocytes layers.

In another study, Cubo et al. [131] used an extrusionbased bioprinter to create a human plasma-derived bilayered skin using fibroblasts and keratinocytes. The dermal component was created by printing fibroblasts embedded within a plasma-derived fibrin hydrogel, which was allowed to polymerize for $30 \mathrm{~min}$ before the seeding of keratinocytes to generate the epidermal component. For in vitro testing, skin constructs were printed on transwell inserts, allowed to differentiate at the air-liquid interface for 17 days and evaluated for their resemblance to the native tissue. Histological analysis showed the formation of skin equivalents with structural resemblance to the human skin, characterized by the presence of spread fibroblasts within the dermal compartment and the terminal differentiation of keratinocytes on the epidermal component. To evaluate the in vivo differentiation capability of printed constructs, the substitutes were printed, incubated overnight and immediately grafted on full-thickness wounds created on the backs of immunodeficient athymic mice. Immunofluorescence results using different differentiation markers indicated the presence of stratum basal, stratum spinosum, stratum granulosum and stratum corneum on the epidermal component, as well as the formation of the dermo-epidermal junction at the interface with the dermal component. Recently, Kim et al. [25] developed a hybrid bioprinting approach to fabricate a human skin model with a functional transwell system in a single-step process, as a low-cost alternative to commercial transwell inserts. In their strategy, an extrusion module capable of printing hydrogel bioinks and thermoplastics was used to print the dermal compartment and a polycaprolactone (PCL) mesh to reduce collagen shrinkage during the construct maturation, respectively. The fibroblast-loaded collagen bioink was printed onto the PCL mesh to create the dermal region, 
while an inkjet module was subsequently applied to print the epidermal region through the deposition of keratinocytes on the top of the dermis-like layer. The dermal region exhibited smaller shrinkage compared to the control group (fibroblasts in collagen gel), while inkjet printed keratinocytes displayed a more uniform distribution and higher proliferation rate when compared to manually deposited cells. After 14 days of ALI culture, fibroblasts were well-spread throughout the dermal region expressing collagen type I, while stratified epidermis were formed on the epidermal region with expression of both early (keratin 10) and late (involucrin) differentiation markers.

\section{Printed skin constructs with appendages and pigmentation}

To create biomimetic skin constructs, the complexity of the tissue must be addressed behind generating the two major macro-structures of skin, i.e., dermal and epidermal layers. Thus, a great deal of interest has recently been focused on the integration of appendage structures into skin constructs, including sweat glands and pigmentation.

The regeneration of sweat glands using 3D printed ECM-mimic environments was addressed by Huang et al. [69] using a gelatin-based bioink. The bioink composed of gelatin, alginate, mouse plantar dermis components (collection of protein molecules with bone morphogenic protein (BMP-4) the predominant growthfactor protein) and EGF was designed to provide a $3 \mathrm{D}$ niche to promote differentiation of epidermal progenitors into sweat gland cells. Several bioink compositions (with or without EGF and with plantar or dorsal dermis components) were printed using an extrusion system, crosslinked with calcium chloride, and their properties evaluated regarding cell viability and differentiation. Cellular hydrogels were deposited onto a cold glass chip (gelatin at gel state) and physically crosslinked with calcium chloride after printing, supporting cell spreading and growth. Results also showed that embedded cells within hydrogel containing EGF and plantar dermis components differentiated into sweat gland cells, as demonstrated by expression of luminal epithelial markers. After the in vitro characterization, 3D constructs were implanted into mice burned paws to access their performance. Printed hydrogels containing both EGF and plantar dermis components restored the sweat gland function upon 14 days of implantation, performing better than the other tested groups. Histological analysis also revealed the formation of sweat glands in regenerated skin and degradation of the hydrogel network. Although this study did not address the mechanisms of sweat gland restoration, the suggested bioprinting approach could be a useful tool for further research on the restoration of skin appendages. In a later study, the same research group demonstrated that the $3 \mathrm{D}$ architecture of printed constructs determines the sweat gland morphogenesis [104]. 3D porous constructs $(20 \times 20 \times 5 \mathrm{~mm})$ were printed using different bioinks (with and without plantar dermis components) and printing nozzles (300 and $400 \mu \mathrm{m})$ and their effect on sweat gland cell differentiation and morphogenesis evaluated. After 14 days of culture, epithelial progenitors in constructs produced with the $300 \mu \mathrm{m}$ nozzle showed higher expression of luminal epithelial markers, which is characteristic of differentiation into sweat gland cells. At later culture period (28 days), specific morphology of sweat gland tissue was only present in constructs printed with the $300 \mu \mathrm{m}$ nozzle and the plantar dermis-containing bioink. The authors suggest that the larger pore size of constructs produced with the $300 \mu \mathrm{m}$ nozzle together with the release of plantar dermis components (inductive factors) from the constructs might influence and guide the differentiation of printed cells. However, the mechanisms and cues that regulate cell response to the $3 \mathrm{D}$ architecture and drive cell differentiation and sweat gland formation still remain unknown.

Skin pigmentation is associated to the production of melanin from melanocytes and its transfer to surrounding keratinocytes, being an important requirement of skin constructs. Min et al. [120] used a micro-valve based bioprinter that deposits small liquid droplets to create full-thickness skin constructs containing pigmentation. The dermal component was created by printing five layers of collagen precursor solution, which was crosslinked through neutralization with sodium bicarbonate. During the fabrication, a suspension of fibroblasts was printed and embedded in the layers 2-4. After 1 day of culture, a suspension of melanocytes was printed on the top of the dermal layer in two different configurations (Fig. 6). After 4 days of culture, a suspension of primary keratinocytes was then printed on the top of the constructs, followed by submerged culture ( 1 day) and ALI culture for 4 days. Histological characterization showed the formation of distinct dermal and epidermal layers with terminal differentiation of keratinocytes, as shown by loricrin staining. Printed melanocytes in the epidermal layer formed multiple clusters of dark pigmentation, as observed by visual inspection and bright-field microscopic images. $\mathrm{H} \& \mathrm{E}$ staining revealed the presence of pigmentation and melanin granules, while Melan-A IHC staining showed that pigmented cluster consisted of melanocytes and keratinocytes, though additional characterization is required to investigate the location of both cell types. Despite promising outcomes, constructs exhibited non-uniform pigmentation, being necessary further optimization to improve the homogeneity in skin pigmentation. 


\section{Printed vascularized skin constructs}

The formation of biologically relevant constructs containing a functional, perfusable vascular network is a major hurdle towards the full implementation and clinical translation of skin bioprinting. Vascularization of bioprinted skin constructs is essential to recapitulate the vasculature of dermis and to provide nutrients and oxygen to the embedded cells. It also plays a key role in the integration of implanted constructs with the host tissue, which remains a limitation of current skin substitutes. In the absence of a functional vascular network, nutrients, oxygen and soluble factors are supplied to the cells by diffusion, which is a slow and inefficient process that may lead to suboptimal cell nutrition, cell necrosis or delayed new tissue formation [158]. In vivo, vascularized tissues contain an organized system of larger blood vessels that branch into smaller vessels, which ultimately branch into capillaries distributed throughout the tissue. Capillaries are in the close proximity (maximum $\sim 200 \mu \mathrm{m}$ ) to the cells allowing nutrition, oxygenation and removal of waste products [167]. The natural formation of a vascular network in vivo is regulated by two underlying processes of vasculogenesis and angiogenesis. The first occurs during early embryonic development to form a primitive capillary network, while the second takes place in adults aiming at the revascularization of damaged or diseased tissues from existing blood vessels [133, 167]. Recapitulating these biological processes in printed tissues is challenging and requires a proper spatiotemporal interplay between vascular cells, resident cells and surrounding ECM. Although several strategies have been explored to promote vascularization in skin constructs [62, 88], engineering branched vascularization in 3D hierarchical architectures remains a great challenge. Bioprinting technologies are attractive to engineer a vascular tree within thick constructs by the precise layer by layer deposition of multiple cell types and ECMlike bioinks into prescribed spatial locations at high resolution [202]. Promising approaches to generate vascular networks have been reported using inkjet [34, 209], laserassisted [203], and extrusion bioprinting [16, 92, 132]. In general, such approaches are based on four main strategies: (1) direct patterning vascular cells onto a receiving substrate [203], (2) continuous printing of polymeric bioink loaded with endothelial cells followed by polymer removal [96], (3) printing perfusable channels in a 3D construct for subsequent injection of a cell suspension into the empty channel [92], and (4) printing of multicellular spheroids [132]. Vascular cells currently explored in bioprinting include endothelial cells such as human umbilical vein endothelial cells HUVECs or human dermal microvascular endothelial cells (HMVECs), and smooth muscle cells such as human umbilical vein smooth muscle cells.

To address the need for vascularization in skin substitutes, Yanez et al. [209] used the inkjet technology to fabricate capillary-like endothelial networks into a dermoepidermal skin graft consisting of neonatal human dermal fibroblasts (NHDFs) and neonatal human epidermal keratinocytes (NHEKs) embedded in a fibrin-collagen matrix. HMVEC were mixed with thrombin and inkjet printed on top of a manually plated layer of collagen-NHDF cells containing fibrinogen. After formation of the fibrin
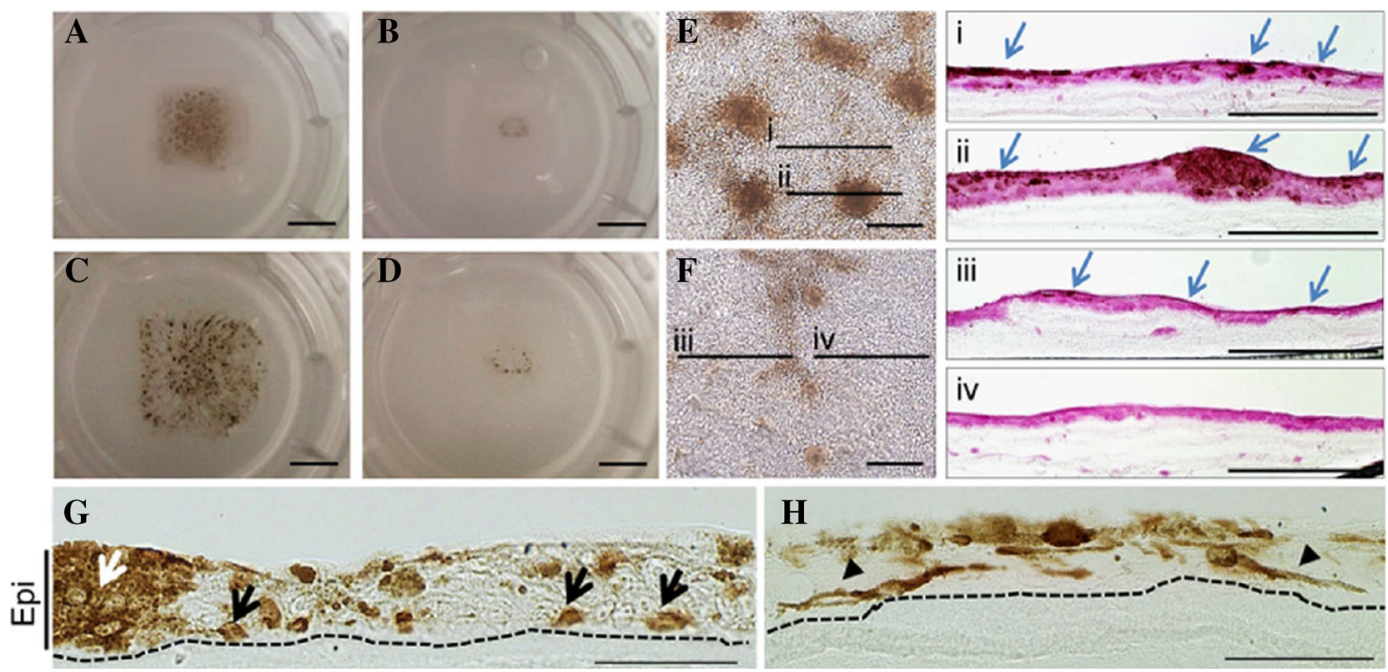

Fig. 6 Printed skin constructs containing melanocytes. a-d Macroscopic images of constructs with melanocytes printed in the area model or spot model before (a, b) and after ALI culture (c, d) (scale bars $5 \mathrm{~mm}$ ). e, f Bright-field images of constructs after ALI culture (scale bars $150 \mu \mathrm{m})$ and respective sections in H\&E staining (i-iv) (scale bars $200 \mu \mathrm{m}$ ). Pigmentation areas are indicated with arrows. g Melan-A expression in the melanocytes/keratinocytes cluster (white arrow) and around the melanocytes in the dermal-epidermal junction (black arrows) (scale bar $100 \mu \mathrm{m})$. h Melan-A expression showing the dendritic form of the viable melanocytes (scale bar $100 \mu \mathrm{m})$ [158] 
hydrogel, a layer of collagen containing NHEK cells was pipetted on top of it to produce bi-layered structures. These structures were then implanted into skin fullthickness wounds on the back of athymic nude mice to investigate healing properties and integration with the native tissue. Wounds treated with printed substitutes required 14-16 days to heal, contrasting with 21 days in the control group (no skin graft) and 28 days in the group implanted with Apligraf ${ }^{\circledR}$ (commercial tissue-engineered skin substitute based on collagen with embedded fibroblasts and further cultured with keratinocytes). Histological characterization of the wounds treated with the printed substitutes on post-operative day 14 showed the formation of dermal and epidermal skin layers similar to the native skin, accompanied by the presence of new micro-vessels in the mouse tissue. It was suggested that new blood vessel formation was stimulated by the presence of endothelial cells, indicating partial integration of the skin graft into the host tissue, which was further confirmed by the presence of human cells in the mouse tissue. More recently, Abaci et al. [1] developed an integrated strategy to generate perfusable vascular networks in human skin equivalents using primary and induced pluripotent stem cell (iPSC)-derived endothelial cells (iECs). 3D printing technology was explored to create moulds with the desired vasculature pattern and functional components for the fabrication of embedded vasculature. Sacrificial channels composed of crosslinked alginate were printed and embedded with dermal fibroblasts embedded with a collagen matrix. After 7 days of culture, keratinocytes were seeded on the top of the dermal compartment, cultured under submerged conditions for 7 days and subsequently maintained at ALI interface for additional 7 days. After this period of time, perfusable channels were created by removing the alginate using a sodium citrate solution, followed by the injection of either HUVECs or iECs, which established proper endothelial barrier function. Vascularized skin constructs grafted on the back of immunodeficient mice for 14 days were perfused with blood, while both non-vascularized constructs and constructs with acellular channels remained non-perfused, which suggest that engineered vasculature promotes and guides neovascularization of skin constructs. Although the skin construct was created by manual deposition of cell-laden solutions rather than using bioprinting technologies, this study reports an integrated approach to generate vascularized skin equivalents for tissue engineering applications. A similar approach to fabricate perfusable vascular channels within skin equivalents was recently reported by Mori et al. [122], who's demonstrated the applicability of the vascularized skin equivalent for dermatological studies and for drug testing.

\section{Conclusions and future perspectives}

The field of skin bioprinting has experienced exciting advances in the direct printing of cellularized hydrogel constructs as effective alternatives to current therapies for skin repair and regeneration. Bioprinting technologies have been applied to create $3 \mathrm{D}$ constructs that recapitulate, to some extent, the architecture and cellular composition of native skin. Although those processes allow the precise patterning of skin cells and ECM components in the form of $3 \mathrm{D}$ constructs capable of promoting in vitro and in vivo skin formation, the field of skin bioprinting is still in an early stage, facing numerous challenges in diverse areas. A critical issue is the availability of bioprinters capable of producing constructs that replicate the intricate ECM composition of skin. Since most of the bioprinters currently used in laboratories result from technical modifications of available technologies and/or equipment, they usually have limited resolution and accuracy, which imposes serious restrictions to the processing conditions, range of printable biomaterials and characteristics of the printed construct. Despite the existence of dedicated bioprinting technologies capable of processing biologically relevant biomaterials and living cells already available for commercialization (e.g., 3D Bioplotter ${ }^{\circledR}, 3$ DDiscovery ${ }^{\circledR}$ ), the printing speed and resolution should be increased in order to better reproduce the heterogeneity found in natural tissues and produce constructs with clinically relevant dimensions in acceptable periods of time. Another important aspect relies on the inclusion of physical and chemical crosslinking methods in the bioprinting process to induce rapid gelation during biofabrication in order to maintain shape fidelity and prevent loss of resolution. The development of hybrid bioprinting approaches for skin tissue engineering, through the combination of bioprinting and other biofabrication techniques with different scales of resolution, is also an important challenge that could enhance the functional outcomes of constructs and overcome technical limitations. Another important limiting factor in skin bioprinting is the lack of printable bioinks exhibiting appropriate rheological, mechanical and biological properties. As a result of the distinctive requisites of each bioprinting strategy, most of the natural and synthetic hydrogels that have been applied for skin wound healing need to be re-engineered to allow adequate processing through bioprinting. Besides printability, such materials must exhibit a plethora of characteristics, including biocompatibility, biodegradability, ability to preserve cell viability and function during/upon printing, appropriate immunological properties and the ability to promote integration with host tissue. Bioinks should also allow the introduction of cell adhesion sites and cleavable bonds to 
control cell behaviour and biomaterial degradation rate, respectively. Current bioinks for skin bioprinting are essentially limited to the use of alginate, collagen, hyaluronic acid and fibrin, which restricts the range of mechanical and biological properties of the fabricated constructs. Although the ability of bioprinting approaches to generate 3D constructs with complex architectures, while allowing good control over the spatial location of biomaterials, cells and biologically active compounds, has already been demonstrated, replicating the complexity of native skin tissues has not yet been successfully achieved. To improve the level of biomimicry, efforts should be made to consider additional aspects regarding the skin appendages, gradients of ECM components, and functional vascular networks. Skin appendages are responsible for several important functions, including protection, sensing and temperature regulation, while the gradients of ECM components play a primordial role in both cell behaviour and biomechanical properties of the skin. Novel bioinks allowing the reproduction of ECM gradients present in different skin layers should be designed and their effects on cell viability and function well characterized and documented towards regulatory approval. Although vascularization is essential for the long-term viability of the construct, it remains a huge challenge in almost all tissue-engineering strategies. Recent developments in bioprinting of functional vascular networks can be explored to design 3D hierarchical skin constructs with embedded vascular cells, which will represent an important advance in the field. Finally, efforts should be concentrated in the translation of bioprinting therapies into clinical practice. This is a long and difficult issue that depends on several factors, including the scaleup of the process, and many regulatory and commercialization aspects. Since novel bioprinting approaches for skin repair and regeneration are complex and multidisciplinary, aspects related to the bioprinting technology, bioinks, cell sources, integration with existing medical devices (e.g., robotic surgical arms, medical imaging systems, real-time imaging technology), automation, reproducibility and affordability must be considered right from an early stage to reduce the time to reach the market. Collaborative work should also be focused on the establishment of good manufacturing practices, standardization of assays to control the properties of manufactured constructs, and methods for the monitoring and inspection of the printing process.

Acknowledgements This work was financially supported by European Regional Development Fund (ERDF) through the COMPETE 2020-Operational Programme for Competitiveness and Internationalization (POCI), Norte Portugal Regional Operational Programme (NORTE 2020), under the PORTUGAL 2020 Partnership Agreement, and by Portuguese funds through Portuguese Foundation for Science and Technology (FCT) in the framework of the project Ref. PTDC/BBB-ECT/2145/2014. Ruben F. Pereira, Aureliana Sousa and Cristina C. Barrias are grateful to FCT for the doctoral grant SFRH/BD/91151/2012, post-doctoral grant SFRH/BPD/90047/2012 and FCT Investigator research position IF/00296/2015 (FCT and $\mathrm{POPH} / \mathrm{ESF})$, respectively.

\section{References}

1. Abaci HE, Guo Z, Coffman A, Gillette B, Lee WH, Sia SK, Christiano AM (2016) Human skin constructs with spatially controlled vasculature using primary and iPSC-derived endothelial cells. Adv Healthc Mater 5(14):1800-1807

2. Abedini F, Ahmadi A, Yavari A, Hosseini V, Mousavi S (2013) Comparison of silver nylon wound dressing and silver sulfadiazine in partial burn wound therapy. Int Wound J 10(5):573-578

3. Ahn S, Lee H, Bonassar LJ, Kim G (2012) Cells (MC3T3-E1)laden alginate scaffolds fabricated by a modified solid-freeform fabrication process supplemented with an aerosol spraying. Biomacromol 13(9):2997-3003

4. Ahn S, Lee H, Puetzer J, Bonassar LJ, Kim G (2012) Fabrication of cell-laden three-dimensional alginate-scaffolds with an aerosol cross-linking process. J Mater Chem 22(36): $18735-18740$

5. Akagi T, Fujiwara T, Akashi M (2014) Inkjet printing of layerby-layer assembled poly(lactide) stereocomplex with encapsulated proteins. Langmuir 30(6):1669-1676

6. Almquist BD, Castleberry SA, Sun JB, Lu AY, Hammond PT (2015) Combination growth factor therapy via electrostatically assembled wound dressings improves diabetic ulcer healing in vivo. Adv Healthc Mater 4(14):2090-2099

7. Annabi N, Tamayol A, Uquillas JA, Akbari M, Bertassoni LE, Cha C, Camci-Unal G, Dokmeci MR, Peppas NA, Khademhosseini A (2014) 25th anniversary article: rational design and applications of hydrogels in regenerative medicine. Adv Mater 26(1):85-123

8. Atiyeh BS, Dibo SA, Hayek SN (2009) Wound cleansing, topical antiseptics and wound healing. Int Wound $\mathrm{J}$ 6(6):420-430

9. Augustin M, Brocatti LK, Rustenbach SJ, Schafer I, Herberger K (2014) Cost-of-illness of leg ulcers in the community. Int Wound J 11(3):283-292

10. Bajaj P, Schweller RM, Khademhosseini A, West JL, Bashir R (2014) 3D biofabrication strategies for tissue engineering and regenerative medicine. Annu Rev Biomed Eng 16(1):247-276

11. Banerjee A, Arha M, Choudhary S, Ashton RS, Bhatia SR, Schaffer DV, Kane RS (2009) The influence of hydrogel modulus on the proliferation and differentiation of encapsulated neural stem cells. Biomaterials 30(27):4695-4699

12. Barbara L, Wen-Kai H, Ian MH, Keith RM (2014) Adult rat retinal ganglion cells and glia can be printed by piezoelectric inkjet printing. Biofabrication 6(1):015001

13. Baroni A, Buommino E, De Gregorio V, Ruocco E, Ruocco V, Wolf R (2012) Structure and function of the epidermis related to barrier properties. Clin Dermatol 30(3):257-262

14. Barron JA, Ringeisen BR, Kim HS, Spargo BJ, Chrisey DB (2004) Application of laser printing to mammalian cells. Thin Solid Films 453:383-387

15. Behrens DT, Villone D, Koch M, Brunner G, Sorokin L, Robenek H, Bruckner-Tuderman L, Bruckner P, Hansen U (2012) The epidermal basement membrane is a composite of separate laminin- or collagen IV-containing networks connected by aggregated perlecan, but not by nidogens. J Biol Chem 287(22):18700-18709 
16. Bertassoni LE, Cecconi M, Manoharan V, Nikkhah M, Hjortnaes J, Cristino AL, Barabaschi G, Demarchi D, Dokmeci MR, Yang Y, Khademhosseini A (2014) Hydrogel bioprinted microchannel networks for vascularization of tissue engineering constructs. Lab Chip 14(13):2202-2211

17. Billiet T, Gevaert E, De Schryver T, Cornelissen M, Dubruel P (2014) The 3D printing of gelatin methacrylamide cell-laden tissue-engineered constructs with high cell viability. Biomaterials 35(1):49-62

18. Binder KW, Zhao WX, Aboushwareb T, Dice D, Atala A, Yoo JJ (2010) In situ bioprinting of the skin for burns. J Am Coll Surg 211(3):S76-S76

19. Blaeser A, Duarte Campos DF, Puster U, Richtering W, Stevens MM, Fischer $\mathrm{H}$ (2016) Controlling shear stress in 3D bioprinting is a key factor to balance printing resolution and stem cell integrity. Adv Healthc Mater 5(3):326-333

20. Blok CS, Vink L, de Boer EM, van Montfrans C, van den Hoogenband HM, Mooij MC, Gauw SA, Vloemans JA, Bruynzeel I, van Kraan A, Kuik J, Waaijman T, Scheper RJ, Gibbs S (2013) Autologous skin substitute for hard-to-heal ulcers: retrospective analysis on safety, applicability, and efficacy in an outpatient and hospitalized setting. Wound Repair Regen 21(5):667-676

21. Boateng JS, Matthews KH, Stevens HN, Eccleston GM (2008) Wound healing dressings and drug delivery systems: a review. J Pharm Sci 97(8):2892-2923

22. Boland T, Mironov V, Gutowska A, Roth EA, Markwald RR (2003) Cell and organ printing 2: fusion of cell aggregates in three-dimensional gels. Anat Rec A Discov Mol Cell Evol Biol 272(2):497-502

23. Bottcher-Haberzeth S, Biedermann T, Klar AS, Widmer DS, Neuhaus K, Schiestl C, Meuli M, Reichmann E (2015) Characterization of pigmented dermo-epidermal skin substitutes in a long-term in vivo assay. Exp Dermatol 24(1):16-21

24. Branco da Cunha C, Klumpers DD, Li WA, Koshy ST, Weaver JC, Chaudhuri O, Granja PL, Mooney DJ (2014) Influence of the stiffness of three-dimensional alginate/collagen-I interpenetrating networks on fibroblast biology. Biomaterials 35(32):8927-8936

25. Byoung Soo K, Jung-Seob L, Ge G, Dong-Woo C (2017) Direct $3 \mathrm{D}$ cell-printing of human skin with functional transwell system. Biofabrication 9(2):025034

26. Caliari SR, Burdick JA (2016) A practical guide to hydrogels for cell culture. Nat Methods 13(5):405-414

27. Catros S, Guillotin B, Bacakova M, Fricain JC, Guillemot F (2011) Effect of laser energy, substrate film thickness and bioink viscosity on viability of endothelial cells printed by laser-assisted bioprinting. Appl Surf Sci 257(12):5142-5147

28. Censi R, Schuurman W, Malda J, di Dato G, Burgisser PE, Dhert WJA, van Nostrum CF, di Martino P, Vermonden T, Hennink WE (2011) A printable photopolymerizable thermosensitive p(HPMAm-lactate)-PEG hydrogel for tissue engineering. Adv Funct Mater 21(10):1833-1842

29. Chahal D, Ahmadi A, Cheung KC (2012) Improving piezoelectric cell printing accuracy and reliability through neutral buoyancy of suspensions. Biotechnol Bioeng 109(11):2932-2940

30. Chang R, Nam J, Sun W (2008) Effects of dispensing pressure and nozzle diameter on cell survival from solid freeform fabrication-based direct cell writing. Tissue Eng Part A 14(1):41-48

31. Chang CC, Boland ED, Williams SK, Hoying JB (2011) Directwrite bioprinting three-dimensional biohybrid systems for future regenerative therapies. J Biomed Mater Res B Appl Biomater 98(1):160-170

32. Chung JHY, Naficy S, Yue ZL, Kapsa R, Quigley A, Moulton SE, Wallace GG (2013) Bio-ink properties and printability for extrusion printing living cells. Biomaterials Science 1(7):763-773

33. Colosi C, Shin SR, Manoharan V, Massa S, Costantini M, Barbetta A, Dokmeci MR, Dentini M, Khademhosseini A (2016) Microfluidic bioprinting of heterogeneous 3D tissue constructs using low-viscosity bioink. Adv Mater 28(4):677-684

34. Cui X, Boland T (2009) Human microvasculature fabrication using thermal inkjet printing technology. Biomaterials 30(31):6221-6227

35. Cui X, Dean D, Ruggeri ZM, Boland T (2010) Cell damage evaluation of thermal inkjet printed Chinese hamster ovary cells. Biotechnol Bioeng 106(6):963-969

36. Cui X, Breitenkamp K, Lotz M, D'Lima D (2012) Synergistic action of fibroblast growth factor- 2 and transforming growth factor-beta1 enhances bioprinted human neocartilage formation. Biotechnol Bioeng 109(9):2357-2368

37. Das S, Pati F, Choi YJ, Rijal G, Shim JH, Kim SW, Ray AR, Cho DW, Ghosh S (2015) Bioprintable, cell-laden silk fibroingelatin hydrogel supporting multilineage differentiation of stem cells for fabrication of three-dimensional tissue constructs. Acta Biomater 11:233-246

38. Derby B (2010) Inkjet printing of functional and structural materials: fluid property requirements, feature stability, and resolution. Annu Rev Mater Res 40(1):395-414

39. Dong YX, Sigen A, Rodrigues M, Li XL, Kwon SH, Kosaric N, Khong S, Gao YS, Wang WX, Gurtner GC (2017) Injectable and tunable gelatin hydrogels enhance stem cell retention and improve cutaneous wound healing. Adv Funct Mater 27(24):n/ a-n/a

40. Driskell RR, Watt FM (2015) Understanding fibroblast heterogeneity in the skin. Trends Cell Biol 25(2):92-99

41. Drury JL, Mooney DJ (2003) Hydrogels for tissue engineering: scaffold design variables and applications. Biomaterials 24(24):4337-4351

42. Duan B, Kapetanovic E, Hockaday LA, Butcher JT (2014) Three-dimensional printed trileaflet valve conduits using biological hydrogels and human valve interstitial cells. Acta Biomater 10(5):1836-1846

43. Dubbin K, Hori Y, Lewis KK, Heilshorn SC (2016) Dual-stage crosslinking of a gel-phase bioink improves cell viability and homogeneity for 3D bioprinting. Adv Healthc Mater 5(19):2488-2492

44. Dumville JC, Worthy G, Bland JM, Cullum N, Dowson C, Iglesias C, Mitchell JL, Nelson EA, Soares MO, Torgerson DJ, Team VI (2009) Larval therapy for leg ulcers (VenUS II): randomised controlled trial. Br Med J 338:b773

45. Fabien G, Vladimir M, Makoto N (2010) Bioprinting is coming of age: report from the International Conference on Bioprinting and Biofabrication in Bordeaux (3B'09). Biofabrication 2(1):010201

46. Fedorovich NE, De Wijn JR, Verbout AJ, Alblas J, Dhert WJ (2008) Three-dimensional fiber deposition of cell-laden, viable, patterned constructs for bone tissue printing. Tissue Eng Part A 14(1):127-133

47. Fonseca KB, Granja PL, Barrias CC (2014) Engineering proteolytically-degradable artificial extracellular matrices. Prog Polym Sci 39(12):2010-2029

48. Gao G, Yonezawa T, Hubbell K, Dai G, Cui X (2015) Inkjetbioprinted acrylated peptides and PEG hydrogel with human mesenchymal stem cells promote robust bone and cartilage formation with minimal printhead clogging. Biotechnol $\mathrm{J}$ 10(10): 1568-1577

49. Gibbs S, van den Hoogenband HM, Kirtschig G, Richters CD, Spiekstra SW, Breetveld M, Scheper RJ, de Boer EM (2006) Autologous full-thickness skin substitute for healing chronic wounds. Br J Dermatol 155(2):267-274 
50. Greaves NS, Iqbal SA, Baguneid M, Bayat A (2013) The role of skin substitutes in the management of chronic cutaneous wounds. Wound Repair Regen 21(2):194-210

51. Greaves NS, Ashcroft KJ, Baguneid M, Bayat A (2013) Current understanding of molecular and cellular mechanisms in fibroplasia and angiogenesis during acute wound healing. J Dermatol Sci 72(3):206-217

52. Groeber F, Holeiter M, Hampel M, Hinderer S, Schenke-Layland K (2011) Skin tissue engineering-in vivo and in vitro applications. Adv Drug Deliv Rev 63(4-5):352-366

53. Gruene M, Deiwick A, Koch L, Schlie S, Unger C, Hofmann N, Bernemann I, Glasmacher B, Chichkov B (2011) Laser printing of stem cells for biofabrication of scaffold-free autologous grafts. Tissue Eng Part C Methods 17(1):79-87

54. Gruene M, Unger C, Koch L, Deiwick A, Chichkov B (2011) Dispensing pico to nanolitre of a natural hydrogel by laserassisted bioprinting. Biomed Eng Online 10(1):19

55. Gruene M, Pflaum M, Hess C, Diamantouros S, Schlie S, Deiwick A, Koch L, Wilhelmi M, Jockenhoevel S, Haverich A, Chichkov B (2011) Laser printing of three-dimensional multicellular arrays for studies of cell-cell and cell-environment interactions. Tissue Eng Part C Methods 17(10):973-982

56. Gu Q, Tomaskovic-Crook E, Lozano R, Chen Y, Kapsa RM, Zhou Q, Wallace GG, Crook JM (2016) Functional 3D neural mini-tissues from printed gel-based bioink and human neural stem cells. Adv Healthc Mater 5(12):1429-1438

57. Guillemot F, Souquet A, Catros S, Guillotin B (2010) Laserassisted cell printing: principle, physical parameters versus cell fate and perspectives in tissue engineering. Nanomedicine (Lond) 5(3):507-515

58. Guillemot F, Souquet A, Catros S, Guillotin B, Lopez J, Faucon M, Pippenger B, Bareille R, Remy M, Bellance S, Chabassier P, Fricain JC, Amedee J (2010) High-throughput laser printing of cells and biomaterials for tissue engineering. Acta Biomater 6(7):2494-2500

59. Guillotin B, Guillemot F (2011) Cell patterning technologies for organotypic tissue fabrication. Trends Biotechnol 29(4):183-190

60. Guillotin B, Souquet A, Catros S, Duocastella M, Pippenger B, Bellance S, Bareille R, Remy M, Bordenave L, Amedee J, Guillemot F (2010) Laser assisted bioprinting of engineered tissue with high cell density and microscale organization. Biomaterials 31(28):7250-7256

61. Guo S, Dipietro LA (2010) Factors affecting wound healing. J Dent Res 89(3):219-229

62. Hendrickx B, Vranckx JJ, Luttun A (2011) Cell-based vascularization strategies for skin tissue engineering. Tissue Eng Part B Rev 17(1):13-24

63. Highley CB, Rodell CB, Burdick JA (2015) Direct 3D printing of shear-thinning hydrogels into self-healing hydrogels. Adv Mater 27(34):5075-5079

64. Hinchliffe RJ, Valk GD, Apelqvist J, Armstrong DG, Bakker K, Game FL, Hartemann-Heurtier A, Londahl M, Price PE, van Houtum WH, Jeffcoate WJ (2008) A systematic review of the effectiveness of interventions to enhance the healing of chronic ulcers of the foot in diabetes. Diabetes Metab Res Rev 24(S1):S119-s144

65. Hoch E, Hirth T, Tovar GEM, Borchers K (2013) Chemical tailoring of gelatin to adjust its chemical and physical properties for functional bioprinting. J Mater Chem B 1(41):5675-5685

66. Hodgkinson T, Bayat A (2011) Dermal substitute-assisted healing: enhancing stem cell therapy with novel biomaterial design. Arch Dermatol Res 303(5):301-315

67. Hoekstra MJ, Westgate SJ, Mueller S (2017) Povidone-iodine ointment demonstrates in vitro efficacy against biofilm formation. Int Wound J 14(1):172-179
68. Horvath L, Umehara Y, Jud C, Blank F, Petri-Fink A, RothenRutishauser B (2015) Engineering an in vitro air-blood barrier by 3D bioprinting. Sci Rep 5:7974

69. Huang S, Yao B, Xie J, Fu X (2016) 3D bioprinted extracellular matrix mimics facilitate directed differentiation of epithelial progenitors for sweat gland regeneration. Acta Biomater 32:170-177

70. Hunt NC, Shelton RM, Grover L (2009) An alginate hydrogel matrix for the localised delivery of a fibroblast/keratinocyte coculture. Biotechnol J 4(5):730-737

71. Imparato G, Urciuolo F, Casale C, Netti PA (2013) The role of microscaffold properties in controlling the collagen assembly in 3D dermis equivalent using modular tissue engineering. Biomaterials 34(32):7851-7861

72. Irvine SA, Agrawal A, Lee BH, Chua HY, Low KY, Lau BC, Machluf M, Venkatraman S (2015) Printing cell-laden gelatin constructs by free-form fabrication and enzymatic protein crosslinking. Biomed Microdevices 17(1):16

73. Jang J, Kim TG, Kim BS, Kim SW, Kwon SM, Cho DW (2016) Tailoring mechanical properties of decellularized extracellular matrix bioink by vitamin B2-induced photo-crosslinking. Acta Biomater 33:88-95

74. Jia J, Richards DJ, Pollard S, Tan Y, Rodriguez J, Visconti RP, Trusk TC, Yost MJ, Yao H, Markwald RR, Mei Y (2014) Engineering alginate as bioink for bioprinting. Acta Biomater 10(10):4323-4331

75. Johnson NR, Wang Y (2013) Controlled delivery of heparinbinding EGF-like growth factor yields fast and comprehensive wound healing. J Control Release 166(2):124-129

76. Jungst T, Smolan W, Schacht K, Scheibel T, Groll J (2016) Strategies and molecular design criteria for 3D printable hydrogels. Chem Rev 116(3):1496-1539

77. Jurczak F, Dugre T, Johnstone A, Offori T, Vujovic Z, Hollander D, Group AASTWS (2007) Randomised clinical trial of Hydrofiber dressing with silver versus povidone-iodine gauze in the management of open surgical and traumatic wounds. Int Wound J 4(1):66-76

78. Jürgen G, Thomas B, Torsten B, Jason AB, Dong-Woo C, Paul DD, Brian D, Gabor F, Qing L, Vladimir AM, Lorenzo M, Makoto N, Wenmiao S, Shoji T, Giovanni V, Tim BFW, Tao X, James JY, Jos M (2016) Biofabrication: reappraising the definition of an evolving field. Biofabrication 8(1):013001

79. Kamel RA, Ong JF, Eriksson E, Junker JP, Caterson EJ (2013) Tissue engineering of skin. J Am Coll Surg 217(3):533-555

80. Kang HW, Lee SJ, Ko IK, Kengla C, Yoo JJ, Atala A (2016) A $3 \mathrm{D}$ bioprinting system to produce human-scale tissue constructs with structural integrity. Nat Biotechnol 34(3):312-319

81. Kazanavicius M, Cepas A, Kolaityte V, Simoliuniene R, Rimdeika $\mathrm{R}$ (2017) The use of modern dressings in managing splitthickness skin graft donor sites: a single-centre randomised controlled trial. J Wound Care 26(6):281-291

82. Kesti M, Muller M, Becher J, Schnabelrauch M, D'Este M, Eglin D, Zenobi-Wong M (2015) A versatile bioink for threedimensional printing of cellular scaffolds based on thermally and photo-triggered tandem gelation. Acta Biomater $11: 162-172$

83. Kesti M, Eberhardt C, Pagliccia G, Kenkel D, Grande D, Boss A, Zenobi-Wong M (2015) Bioprinting complex cartilaginous structures with clinically compliant biomaterials. Adv Funct Mater 25(48):7406-7417

84. Khorasani G, Hosseinimehr SJ, Azadbakht M, Zamani A, Mahdavi MR (2009) Aloe versus silver sulfadiazine creams for second-degree burns: a randomized controlled study. Surg Today 39(7):587-591

85. Kim JD, Choi JS, Kim BS, Choi YC, Cho YW (2010) Piezoelectric inkjet printing of polymers: stem cell patterning on polymer substrates. Polymer 51(10):2147-2154 
86. Kim H, Kong WH, Seong KY, Sung DK, Jeong H, Kim JK, Yang SY, Hahn SK (2016) Hyaluronate-epidermal growth factor conjugate for skin wound healing and regeneration. Biomacromol 17(11):3694-3705

87. Kirsner RS, Marston WA, Snyder RJ, Lee TD, Cargill DI, Slade HB (2012) Spray-applied cell therapy with human allogeneic fibroblasts and keratinocytes for the treatment of chronic venous leg ulcers: a phase 2, multicentre, double-blind, randomised, placebo-controlled trial. Lancet 380(9846):977-985

88. Klar AS, Guven S, Biedermann T, Luginbuhl J, BottcherHaberzeth S, Meuli-Simmen C, Meuli M, Martin I, Scherberich A, Reichmann E (2014) Tissue-engineered dermo-epidermal skin grafts prevascularized with adipose-derived cells. Biomaterials 35(19):5065-5078

89. Koch L, Kuhn S, Sorg H, Gruene M, Schlie S, Gaebel R, Polchow B, Reimers K, Stoelting S, Ma N, Vogt PM, Steinhoff G, Chichkov B (2010) Laser printing of skin cells and human stem cells. Tissue Eng Part C Methods 16(5):847-854

90. Koch L, Deiwick A, Schlie S, Michael S, Gruene M, Coger V, Zychlinski D, Schambach A, Reimers K, Vogt PM, Chichkov B (2012) Skin tissue generation by laser cell printing. Biotechnol Bioeng 109(7):1855-1863

91. Kolesky DB, Truby RL, Gladman AS, Busbee TA, Homan KA, Lewis JA (2014) 3D bioprinting of vascularized, heterogeneous cell-laden tissue constructs. Adv Mater 26(19):3124-3130

92. Kolesky DB, Homan KA, Skylar-Scott MA, Lewis JA (2016) Three-dimensional bioprinting of thick vascularized tissues. Proc Natl Acad Sci USA 113(12):3179-3184

93. Lee W, Debasitis JC, Lee VK, Lee JH, Fischer K, Edminster K, Park JK, Yoo SS (2009) Multi-layered culture of human skin fibroblasts and keratinocytes through three-dimensional freeform fabrication. Biomaterials 30(8):1587-1595

94. Lee BK, Yun YH, Choi JS, Choi YC, Kim JD, Cho YW (2012) Fabrication of drug-loaded polymer microparticles with arbitrary geometries using a piezoelectric inkjet printing system. Int J Pharm 427(2):305-310

95. Lee V, Singh G, Trasatti JP, Bjornsson C, Xu X, Tran TN, Yoo SS, Dai G, Karande P (2014) Design and fabrication of human skin by three-dimensional bioprinting. Tissue Eng Part C Methods 20(6):473-484

96. Lee VK, Kim DY, Ngo H, Lee Y, Seo L, Yoo SS, Vincent PA, Dai G (2014) Creating perfused functional vascular channels using 3D bio-printing technology. Biomaterials 35(28):8092-8102

97. Lee DY, Lee H, Kim Y, Yoo SY, Chung WJ, Kim G (2016) Phage as versatile nanoink for printing 3-D cell-laden scaffolds. Acta Biomater 29:112-124

98. Leto Barone AA, Mastroianni M, Farkash EA, Mallard C, Albritton A, Torabi R, Leonard DA, Kurtz JM, Sachs DH, Cetrulo CL Jr (2015) Genetically modified porcine split-thickness skin grafts as an alternative to allograft for provision of temporary wound coverage: preliminary characterization. Burns 41(3):565-574

99. Li PN, Li H, Zhong LX, Sun Y, Yu LJ, Wu ML, Zhang LL, Kong QY, Wang SY, Lv DC (2015) Molecular events underlying maggot extract promoted rat in vivo and human in vitro skin wound healing. Wound Repair Regen 23(1):65-73

100. Li C, Faulkner-Jones A, Dun AR, Jin J, Chen P, Xing Y, Yang Z, Li Z, Shu W, Liu D, Duncan RR (2015) Rapid formation of a supramolecular polypeptide-DNA hydrogel for in situ three-dimensional multilayer bioprinting. Angew Chem Int Ed Engl 54(13):3957-3961

101. Lin Y, Bourell D, Huang G, Huang Y, Jeremy Tzeng TR, Chrisey D (2010) Effect of laser fluence in laser-assisted direct writing of human colon cancer cell. Rapid Prototyp J 16(3):202-208
102. Liu JS, Gartner ZJ (2012) Directing the assembly of spatially organized multicomponent tissues from the bottom up. Trends Cell Biol 22(12):683-691

103. Liu SJ, Kau YC, Chou CY, Chen JK, Wu RC, Yeh WL (2010) Electrospun PLGA/collagen nanofibrous membrane as earlystage wound dressing. J Membr Sci 355(1-2):53-59

104. Liu N, Huang S, Yao B, Xie J, Wu X, Fu X (2016) 3D bioprinting matrices with controlled pore structure and release function guide in vitro self-organization of sweat gland. Sci Rep 6:34410

105. Liu W, Zhang YS, Heinrich MA, De Ferrari F, Jang HL, Bakht SM, Alvarez MM, Yang J, Li YC, Trujillo-de Santiago G, Miri AK, Zhu K, Khoshakhlagh P, Prakash G, Cheng H, Guan X, Zhong Z, Ju J, Zhu GH, Jin X, Shin SR, Dokmeci MR, Khademhosseini A (2017) Rapid continuous multimaterial extrusion bioprinting. Adv Mater 29(3):n/a-n/a

106. Lootens L, Brusselaers N, Beele H, Monstrey S (2013) Keratinocytes in the treatment of severe burn injury: an update. Int Wound J 10(1):6-12

107. Luiz EB, Juliana CC, Vijayan M, Ana LC, Nupura SB, Wesleyan AA, Pinar Z, Nihal EV, Amir MG, Mehmet RD, Ali K (2014) Direct-write bioprinting of cell-laden methacrylated gelatin hydrogels. Biofabrication 6(2):024105

108. Lutolf MP, Hubbell JA (2005) Synthetic biomaterials as instructive extracellular microenvironments for morphogenesis in tissue engineering. Nat Biotechnol 23(1):47-55

109. MacNeil S (2007) Progress and opportunities for tissue-engineered skin. Nature 445(7130):874-880

110. Mahdavian Delavary B, van der Veer WM, van Egmond M, Niessen FB, Beelen RH (2011) Macrophages in skin injury and repair. Immunobiology 216(7):753-762

111. Malda J, Visser J, Melchels FP, Jungst T, Hennink WE, Dhert WJ, Groll J, Hutmacher DW (2013) 25th anniversary article: engineering hydrogels for biofabrication. Adv Mater 25(36):5011-5028

112. Markstedt K, Mantas A, Tournier I, Martinez Avila H, Hagg D, Gatenholm P (2015) 3D bioprinting human chondrocytes with nanocellulose-alginate bioink for cartilage tissue engineering applications. Biomacromolecules 16(5):1489-1496

113. Martin P, Leibovich SJ (2005) Inflammatory cells during wound repair: the good, the bad and the ugly. Trends Cell Biol 15(11):599-607

114. Masters KS, Leibovich SJ, Belem P, West JL, Poole-Warren LA (2002) Effects of nitric oxide releasing poly(vinyl alcohol) hydrogel dressings on dermal wound healing in diabetic mice. Wound Repair Regen 10(5):286-294

115. Mayet N, Choonara YE, Kumar P, Tomar LK, Tyagi C, Du Toit LC, Pillay V (2014) A comprehensive review of advanced biopolymeric wound healing systems. J Pharm Sci 103(8):2211-2230

116. Melchels FPW, Domingos MAN, Klein TJ, Malda J, Bartolo PJ, Hutmacher DW (2012) Additive manufacturing of tissues and organs. Prog Polym Sci 37(8):1079-1104

117. Michael S, Sorg H, Peck CT, Koch L, Deiwick A, Chichkov B, Vogt PM, Reimers K (2013) Tissue engineered skin substitutes created by laser-assisted bioprinting form skin-like structures in the dorsal skin fold chamber in mice. PLoS One 8(3):e57741

118. Michael M, Jana B, Matthias S, Marcy Z-W (2015) Nanostructured pluronic hydrogels as bioinks for 3D bioprinting. Biofabrication 7(3):035006

119. Miller ED, Li K, Kanade T, Weiss LE, Walker LM, Campbell PG (2011) Spatially directed guidance of stem cell population migration by immobilized patterns of growth factors. Biomaterials 32(11):2775-2785

120. Min D, Lee W, Bae IH, Lee TR, Croce P, Yoo SS (2017) Bioprinting of biomimetic skin containing melanocytes. Exp Dermatol:n/a-n/a 
121. Mironov V, Visconti RP, Kasyanov V, Forgacs G, Drake CJ, Markwald RR (2009) Organ printing: tissue spheroids as building blocks. Biomaterials 30(12):2164-2174

122. Mori N, Morimoto Y, Takeuchi S (2017) Skin integrated with perfusable vascular channels on a chip. Biomaterials 116:48-56

123. Muhammad A, Emeline P, Alexandre D, Aurelien F, Fabien G (2014) Controlling laser-induced jet formation for bioprinting mesenchymal stem cells with high viability and high resolution. Biofabrication 6(4):045001

124. Murakami K, Aoki H, Nakamura S, Nakamura S, Takikawa M, Hanzawa M, Kishimoto S, Hattori H, Tanaka Y, Kiyosawa T, Sato Y, Ishihara M (2010) Hydrogel blends of chitin/chitosan, fucoidan and alginate as healing-impaired wound dressings. Biomaterials 31(1):83-90

125. Murphy SV, Atala A (2014) 3D bioprinting of tissues and organs. Nat Biotechnol 32(8):773-785

126. Murphy SV, Skardal A, Atala A (2013) Evaluation of hydrogels for bio-printing applications. J Biomed Mater Res A 101(1):272-284

127. Nair K, Gandhi M, Khalil S, Yan KC, Marcolongo M, Barbee K, Sun W (2009) Characterization of cell viability during bioprinting processes. Biotechnol J 4(8):1168-1177

128. Nathan RS, David TC, Yong H, Nurazhani Abdul R, Yubing X, Douglas BC (2010) Laser-based direct-write techniques for cell printing. Biofabrication 2(3):032001

129. Nichol JW, Khademhosseini A (2009) Modular tissue engineering: engineering biological tissues from the bottom up. Soft Matter 5(7):1312-1319

130. Nichol JW, Koshy ST, Bae H, Hwang CM, Yamanlar S, Khademhosseini A (2010) Cell-laden microengineered gelatin methacrylate hydrogels. Biomaterials 31(21):5536-5544

131. Nieves C, Marta G, Juan FdC, Diego V, Jose LJ (2017) 3D bioprinting of functional human skin: production and in vivo analysis. Biofabrication 9(1):015006

132. Norotte C, Marga FS, Niklason LE, Forgacs G (2009) Scaffoldfree vascular tissue engineering using bioprinting. Biomaterials 30(30):5910-5917

133. Novosel EC, Kleinhans C, Kluger PJ (2011) Vascularization is the key challenge in tissue engineering. Adv Drug Deliv Rev 63(4-5):300-311

134. Odde DJ, Renn MJ (2000) Laser-guided direct writing of living cells. Biotechnol Bioeng 67(3):312-318

135. Ouyang L, Highley CB, Sun W, Burdick JA (2017) A generalizable strategy for the 3D bioprinting of hydrogels from nonviscous photo-crosslinkable inks. Adv Mater 29(8):n/a-n/a

136. Ozbolat IT (2015) Bioprinting scale-up tissue and organ constructs for transplantation. Trends Biotechnol 33(7):395-400

137. Ozbolat IT, Hospodiuk M (2016) Current advances and future perspectives in extrusion-based bioprinting. Biomaterials 76:321-343

138. Pajardi G, Rapisarda V, Somalvico F, Scotti A, Russo GL, Ciancio F, Sgro A, Nebuloni M, Allevi R, Torre ML, Trabucchi E, Marazzi M (2016) Skin substitutes based on allogenic fibroblasts or keratinocytes for chronic wounds not responding to conventional therapy: a retrospective observational study. Int Wound J 13(1):44-52

139. Palmiero C, Imparato G, Urciuolo F, Netti P (2010) Engineered dermal equivalent tissue in vitro by assembly of microtissue precursors. Acta Biomater 6(7):2548-2553

140. Park J, Moon J (2006) Control of colloidal particle deposit patterns within picoliter droplets ejected by ink-jet printing. Langmuir 22(8):3506-3513

141. Parzel CA, Pepper ME, Burg T, Groff RE, Burg KJ (2009) EDTA enhances high-throughput two-dimensional bioprinting by inhibiting salt scaling and cell aggregation at the nozzle surface. J Tissue Eng Regen Med 3(4):260-268
142. Pasparakis M, Haase I, Nestle FO (2014) Mechanisms regulating skin immunity and inflammation. Nat Rev Immunol 14(5):289-301

143. Pati F, Jang J, Ha DH, Won Kim S, Rhie JW, Shim JH, Kim DH, Cho DW (2014) Printing three-dimensional tissue analogues with decellularized extracellular matrix bioink. Nat Commun 5:3935

144. Pati F, Ha DH, Jang J, Han HH, Rhie JW, Cho DW (2015) Biomimetic 3D tissue printing for soft tissue regeneration. Biomaterials 62:164-175

145. Pereira RF, Bartolo PJ (2016) Traditional therapies for skin wound healing. Adv Wound Care (New Rochelle) 5(5):208-229

146. Pereira RF, Bártolo PJ (2014) 10.10-recent advances in additive biomanufacturing. In: Yilbas SHFBJVT (ed) Comprehensive materials processing. Elsevier, Oxford, pp 265-284. doi:10. 1016/B978-0-08-096532-1.01009-8

147. Pereira R, Bártolo P (2014) Photocrosslinkable materials for the fabrication of tissue-engineered constructs by stereolithography. In: Fernandes PR, Bartolo PJ (eds) Tissue engineering, vol 31. Computational methods in applied sciences. Springer Netherlands, pp 149-178. doi:10.1007/978-94-007-7073-7_8

148. Pereira RF, Bártolo PJ (2015) 3D photo-fabrication for tissue engineering and drug delivery. Engineering 1(1):090-112

149. Pereira RF, Barrias CC, Granja PL, Bartolo PJ (2013) Advanced biofabrication strategies for skin regeneration and repair. Nanomedicine (Lond) 8(4):603-621

150. Pereira RF, Carvalho A, Gil MH, Mendes A, Bartolo PJ (2013) Influence of Aloe vera on water absorption and enzymatic in vitro degradation of alginate hydrogel films. Carbohydr Polym 98(1):311-320

151. Pereira R, Carvalho A, Vaz DC, Gil MH, Mendes A, Bartolo P (2013) Development of novel alginate based hydrogel films for wound healing applications. Int J Biol Macromol 52:221-230

152. Pescosolido L, Schuurman W, Malda J, Matricardi P, Alhaique F, Coviello T, van Weeren PR, Dhert WJ, Hennink WE, Vermonden T (2011) Hyaluronic acid and dextran-based semi-IPN hydrogels as biomaterials for bioprinting. Biomacromol 12(5):1831-1838

153. Phillips CJ, Humphreys I, Fletcher J, Harding K, Chamberlain G, Macey S (2016) Estimating the costs associated with the management of patients with chronic wounds using linked routine data. Int Wound J 13(6):1193-1197

154. Poldervaart MT, Wang $H$, van der Stok J, Weinans $H$, Leeuwenburgh SC, Oner FC, Dhert WJ, Alblas J (2013) Sustained release of BMP-2 in bioprinted alginate for osteogenicity in mice and rats. PLoS One 8(8):e72610

155. Poldervaart MT, Gremmels H, van Deventer K, Fledderus JO, Oner FC, Verhaar MC, Dhert WJ, Alblas J (2014) Prolonged presence of VEGF promotes vascularization in 3D bioprinted scaffolds with defined architecture. J Control Release 184:58-66

156. Pourchet LJ, Thepot A, Albouy M, Courtial EJ, Boher A, Blum LJ, Marquette CA (2017) Human skin 3D bioprinting using scaffold-free approach. Adv Healthc Mater 6(4). doi:10.1002/ adhm.201601101

157. Proksch E, Brandner JM, Jensen JM (2008) The skin: an indispensable barrier. Exp Dermatol 17(12):1063-1072

158. Radisic M, Yang L, Boublik J, Cohen RJ, Langer R, Freed LE, Vunjak-Novakovic G (2004) Medium perfusion enables engineering of compact and contractile cardiac tissue. Am J Physiol Heart Circ Physiol 286(2):H507-H516

159. Rashidi MK, Mirazi N, Hosseini A (2016) Effect of topical mixture of honey, royal jelly and olive oil-propolis extract on skin wound healing in diabetic rats. Wound Med 12:6-9

160. Reijnders CM, van Lier A, Roffel S, Kramer D, Scheper RJ, Gibbs S (2015) Development of a full-thickness human skin equivalent in vitro model derived from TERT-immortalized keratinocytes and fibroblasts. Tissue Eng Part A 21(17-18):2448-2459 
161. Reyes-Ortega F, Cifuentes A, Rodriguez G, Aguilar MR, Gonzalez-Gomez A, Solis R, Garcia-Honduvilla N, Bujan J, GarciaSanmartin J, Martinez A, Roman JS (2015) Bioactive bilayered dressing for compromised epidermal tissue regeneration with sequential activity of complementary agents. Acta Biomater 23:103-115

162. Riccardo L, Jetze V, Josep AP, Elisabeth E, Jos M, Miguel AM$\mathrm{T}$ (2014) Biofabrication of tissue constructs by 3D bioprinting of cell-laden microcarriers. Biofabrication 6(3):035020

163. Riggs BC, Dias AD, Schiele NR, Cristescu R, Huang Y, Corr DT, Chrisey DB (2011) Matrix-assisted pulsed laser methods for biofabrication. MRS Bull 36(12):1043-1050

164. Rimann M, Bono E, Annaheim H, Bleisch M, Graf-Hausner U (2016) Standardized 3D bioprinting of soft tissue models with human primary cells. J Lab Autom 21(4):496-509

165. Ringeisen BR, Othon CM, Barron JA, Young D, Spargo BJ (2006) Jet-based methods to print living cells. Biotechnol J 1(9):930-948

166. Rioja AY, Tiruvannamalai Annamalai R, Paris S, Putnam AJ, Stegemann JP (2016) Endothelial sprouting and network formation in collagen- and fibrin-based modular microbeads. Acta Biomater 29:33-41

167. Rouwkema J, Khademhosseini A (2016) Vascularization and angiogenesis in tissue engineering: beyond creating static networks. Trends Biotechnol 34(9):733-745

168. Rúben FP, Paulo JB (2014) Photopolymerizable hydrogels in regenerative medicine and drug delivery. In: Hot topics in biomaterials. Future science book series. Future Science Ltd, pp 6-28. doi:10.4155/ebo.13.650

169. Rutz AL, Hyland KE, Jakus AE, Burghardt WR, Shah RN (2015) A multimaterial bioink method for 3D printing tunable, cell-compatible hydrogels. Adv Mater 27(9):1607-1614

170. Saunders RE, Derby B (2014) Inkjet printing biomaterials for tissue engineering: bioprinting. Int Mater Rev 59(8):430-448

171. Saunders RE, Gough JE, Derby B (2008) Delivery of human fibroblast cells by piezoelectric drop-on-demand inkjet printing. Biomaterials 29(2):193-203

172. Schon BS, Hooper GJ, Woodfield TB (2017) Modular tissue assembly strategies for biofabrication of engineered cartilage. Ann Biomed Eng 45(1):100-114

173. Schuurman W, Khristov V, Pot MW, van Weeren PR, Dhert WJ, Malda J (2011) Bioprinting of hybrid tissue constructs with tailorable mechanical properties. Biofabrication 3(2):021001

174. Schuurman W, Levett PA, Pot MW, van Weeren PR, Dhert WJ, Hutmacher DW, Melchels FP, Klein TJ, Malda J (2013) Gelatinmethacrylamide hydrogels as potential biomaterials for fabrication of tissue-engineered cartilage constructs. Macromol Biosci 13(5):551-561

175. Sen CK, Gordillo GM, Roy S, Kirsner R, Lambert L, Hunt TK, Gottrup F, Gurtner GC, Longaker MT (2009) Human skin wounds: a major and snowballing threat to public health and the economy. Wound Repair Regen 17(6):763-771

176. Shevchenko RV, James SL, James SE (2010) A review of tissueengineered skin bioconstructs available for skin reconstruction. J R Soc Interface 7(43):229-258

177. Shevchenko RV, Eeman M, Rowshanravan B, Allan IU, Savina IN, Illsley M, Salmon M, James SL, Mikhalovsky SV, James SE (2014) The in vitro characterization of a gelatin scaffold, prepared by cryogelation and assessed in vivo as a dermal replacement in wound repair. Acta Biomater 10(7):3156-3166

178. Sidgwick GP, Bayat A (2012) Extracellular matrix molecules implicated in hypertrophic and keloid scarring. J Eur Acad Dermatol Venereol 26(2):141-152

179. Sidgwick GP, McGeorge D, Bayat A (2015) A comprehensive evidence-based review on the role of topicals and dressings in the management of skin scarring. Arch Dermatol Res 307(6):461-477

180. Sidgwick GP, McGeorge D, Bayat A (2015) A comprehensive evidence-based review on the role of topicals and dressings in the management of skin scarring. Arch Dermatol Res 306:1-17

181. Sivamani RK, Ma BR, Wehrli LN, Maverakis E (2012) Phytochemicals and naturally derived substances for wound healing. Adv Wound Care (New Rochelle) 1(5):213-217

182. Skardal A, Zhang J, McCoard L, Xu X, Oottamasathien S, Prestwich GD (2010) Photocrosslinkable hyaluronan-gelatin hydrogels for two-step bioprinting. Tissue Eng Part A 16(8):2675-2685

183. Skardal A, Zhang J, McCoard L, Oottamasathien S, Prestwich GD (2010) Dynamically crosslinked gold nanoparticlehyaluronan hydrogels. Adv Mater 22(42):4736-4740

184. Skardal A, Mack D, Kapetanovic E, Atala A, Jackson JD, Yoo J, Soker S (2012) Bioprinted amniotic fluid-derived stem cells accelerate healing of large skin wounds. Stem Cells Transl Med 1(11):792-802

185. Skardal A, Devarasetty M, Kang HW, Mead I, Bishop C, Shupe T, Lee SJ, Jackson J, Yoo J, Soker S, Atala A (2015) A hydrogel bioink toolkit for mimicking native tissue biochemical and mechanical properties in bioprinted tissue constructs. Acta Biomater 25:24-34

186. Skardal A, Murphy SV, Crowell K, Mack D, Atala A, Soker S (2016) A tunable hydrogel system for long-term release of cellsecreted cytokines and bioprinted in situ wound cell delivery. J Biomed Mater Res B Appl Biomater:n/a-n/a

187. Sriram G, Bigliardi PL, Bigliardi-Qi M (2015) Fibroblast heterogeneity and its implications for engineering organotypic skin models in vitro. Eur J Cell Biol 94(11):483-512

188. Strodtbeck F (2001) Physiology of wound healing. Newborn Infant Nurs Rev 1(1):43-52

189. Sun G, Zhang X, Shen YI, Sebastian R, Dickinson LE, FoxTalbot K, Reinblatt M, Steenbergen C, Harmon JW, Gerecht S (2011) Dextran hydrogel scaffolds enhance angiogenic responses and promote complete skin regeneration during burn wound healing. Proc Natl Acad Sci USA 108(52):20976-20981

190. Tao H, Marelli B, Yang M, An B, Onses MS, Rogers JA, Kaplan DL, Omenetto FG (2015) Inkjet printing of regenerated silk fibroin: from printable forms to printable functions. Adv Mater 27(29):4273-4279

191. Tasoglu S, Demirci U (2013) Bioprinting for stem cell research. Trends Biotechnol 31(1):10-19

192. Thu HE, Zulfakar MH, Ng SF (2012) Alginate based bilayer hydrocolloid films as potential slow-release modern wound dressing. Int J Pharm 434(1-2):375-383

193. Tirella A, Orsini A, Vozzi G, Ahluwalia A (2009) A phase diagram for microfabrication of geometrically controlled hydrogel scaffolds. Biofabrication 1(4):045002

194. Tirella A, Vozzi F, De Maria C, Vozzi G, Sandri T, Sassano D, Cognolato L, Ahluwalia A (2011) Substrate stiffness influences high resolution printing of living cells with an ink-jet system. J Biosci Bioeng 112(1):79-85

195. Tong C, Hao H, Xia L, Liu J, Ti D, Dong L, Hou Q, Song H, Liu H, Zhao Y, Fu X, Han W (2016) Hypoxia pretreatment of bone marrow-derived mesenchymal stem cells seeded in a collagenchitosan sponge scaffold promotes skin wound healing in diabetic rats with hindlimb ischemia. Wound Repair Regen 24(1):45-56

196. Tsukahara K, Takema Y, Moriwaki S, Fujimura T, Imokawa G (2001) Dermal fluid translocation is an important determinant of the diurnal variation in human skin thickness. Br J Dermatol 145(4):590-596

197. Ud-Din S, Volk SW, Bayat A (2014) Regenerative healing, scarfree healing and scar formation across the species: current concepts and future perspectives. Exp Dermatol 23(9):615-619 
198. Van Tomme SR, Storm G, Hennink WE (2008) In situ gelling hydrogels for pharmaceutical and biomedical applications. Int $\mathrm{J}$ Pharm 355(1-2):1-18

199. Van Vlierberghe S, Dubruel P, Schacht E (2011) Biopolymerbased hydrogels as scaffolds for tissue engineering applications: a review. Biomacromol 12(5):1387-1408

200. Virginie K, Fabien G, Isabelle A, Bertrand G, Sylvain M, Joëlle A, Jean-Christophe F, Sylvain C (2010) In vivo bioprinting for computer- and robotic-assisted medical intervention: preliminary study in mice. Biofabrication 2(1):014101

201. Volk SW, Iqbal SA, Bayat A (2013) Interactions of the extracellular matrix and progenitor cells in cutaneous wound healing. Adv Wound Care (New Rochelle) 2(6):261-272

202. Vyas C, Pereira R, Huang B, Liu F, Wang W, Bartolo P (2017) Engineering the vasculature with additive manufacturing. Curr Opin Biomed Eng 2:1-13

203. Wu PK, Ringeisen BR (2010) Development of human umbilical vein endothelial cell (HUVEC) and human umbilical vein smooth muscle cell (HUVSMC) branch/stem structures on hydrogel layers via biological laser printing (BioLP). Biofabrication 2(1):014111

204. Wust S, Godla ME, Muller R, Hofmann S (2014) Tunable hydrogel composite with two-step processing in combination with innovative hardware upgrade for cell-based three-dimensional bioprinting. Acta Biomater 10(2):630-640

205. Xie Y, Rizzi SC, Dawson R, Lynam E, Richards S, Leavesley DI, Upton Z (2010) Development of a three-dimensional human skin equivalent wound model for investigating novel wound healing therapies. Tissue Eng Part C Methods 16(5):1111-1123
206. Xu T, Jin J, Gregory C, Hickman JJ, Boland T (2005) Inkjet printing of viable mammalian cells. Biomaterials 26(1):93-99

207. Xu T, Rohozinski J, Zhao W, Moorefield EC, Atala A, Yoo JJ (2009) Inkjet-mediated gene transfection into living cells combined with targeted delivery. Tissue Eng Part A 15(1):95-101

208. Xu T, Binder KW, Albanna MZ, Dice D, Zhao W, Yoo JJ, Atala A (2013) Hybrid printing of mechanically and biologically improved constructs for cartilage tissue engineering applications. Biofabrication 5(1):015001

209. Yanez M, Rincon J, Dones A, De Maria C, Gonzales R, Boland $\mathrm{T}$ (2015) In vivo assessment of printed microvasculature in a bilayer skin graft to treat full-thickness wounds. Tissue Eng Part A 21(1-2):224-233

210. Yang JA, Yeom J, Hwang BW, Hoffman AS, Hahn SK (2014) In situ-forming injectable hydrogels for regenerative medicine. Prog Polym Sci 39(12):1973-1986

211. Yeo M, Lee JS, Chun W, Kim GH (2016) An innovative collagen-based cell-printing method for obtaining human adipose stem cell-laden structures consisting of core-sheath structures for tissue engineering. Biomacromolecules 17(4):1365-1375

212. Zhang L, Chen J, Han C (2009) A multicenter clinical trial of recombinant human GM-CSF hydrogel for the treatment of deep second-degree burns. Wound Repair Regen 17(5):685-689

213. Zheng Q, Lu J, Chen H, Huang L, Cai J, Xu Z (2011) Application of inkjet printing technique for biological material delivery and antimicrobial assays. Anal Biochem 410(2):171-176 